\title{
Mechanisms of Key Innate Immune Cells in Early- and Late-Onset Preeclampsia
}

\author{
Ingrid Aneman ${ }^{1 \dagger}$, Dillan Pienaar ${ }^{1 \dagger}$, Sonja Suvakov ${ }^{2}$, Tatjana P. Simic ${ }^{3,4}$, Vesna D. Garovic ${ }^{2 \star}$ \\ and Lana McClements ${ }^{1 *}$ \\ ${ }^{1}$ Faculty of Science, School of Life Sciences, University of Technology Sydney, Sydney, NSW, Australia, ${ }^{2}$ Division of \\ Nephrology and Hypertension, Department of Internal Medicine, Mayo Clinic, Rochester, MN, United States, ${ }^{3}$ Faculty of \\ Medicine, Institute of Medical and Clinical Biochemistry, University of Belgrade, Belgrade, Serbia, ${ }^{4}$ Department of Medical \\ Sciences, Serbian Academy of Sciences and Arts, Belgrade, Serbia
}

OPEN ACCESS

Edited by:

Sherry Fleming,

Kansas State University, United States

Reviewed by:

Sandy Davidge,

University of Alberta, Canada

Piyali Chatterjee,

Central Texas Veterans Health Care

System, United States

*Correspondence:

Vesna D. Garovic

Garovic.Vesna@mayo.edu

Lana McClements

Lana.mcclements@uts.edu.au

†These authors have contributed equally to this work

Specialty section:

This article was submitted to

Molecular Innate Immunity,

a section of the journal

Frontiers in Immunology

Received: 29 May 2020

Accepted: 10 July 2020

Published: 18 August 2020

Citation:

Aneman I, Pienaar D, Suvakov S,

Simic TP, Garovic VD and

McClements L (2020) Mechanisms of

Key Innate Immune Cells in Early- and

Late-Onset Preeclampsia.

Front. Immunol. 11:1864.

doi: 10.3389/fimmu.2020.01864
Preeclampsia is a complex cardiovascular disorder of pregnancy with underlying multifactorial pathogeneses; however, its etiology is not fully understood. It is characterized by the new onset of maternal hypertension after 20 weeks of gestation, accompanied by proteinuria, maternal organ damage, and/or uteroplacental dysfunction. Preeclampsia can be subdivided into early- and late-onset phenotypes (EOPE and LOPE), diagnosed before 34 weeks or from 34 weeks of gestation, respectively. Impaired placental development in early pregnancy and subsequent growth restriction is often associated with EOPE, while LOPE is associated with maternal endothelial dysfunction. The innate immune system plays an essential role in normal progression of physiological pregnancy and fetal development. However, inappropriate or excessive activation of this system can lead to placental dysfunction or poor maternal vascular adaptation and contribute to the development of preeclampsia. This review aims to comprehensively outline the mechanisms of key innate immune cells including macrophages, neutrophils, natural killer (NK) cells, and innate B1 cells, in normal physiological pregnancy, EOPE and LOPE. The roles of the complement system, syncytiotrophoblast extracellular vesicles and mesenchymal stem cells (MSCs) are also discussed in the context of innate immune system regulation and preeclampsia. The outlined molecular mechanisms, which represent potential therapeutic targets, and associated emerging treatments, are evaluated as treatments for preeclampsia. Therefore, by addressing the current understanding of innate immunity in the pathogenesis of EOPE and LOPE, this review will contribute to the body of research that could lead to the development of better diagnosis, prevention, and treatment strategies. Importantly, it will delineate the differences in the mechanisms of the innate immune system in two different types of preeclampsia, which is necessary for a more personalized approach to the monitoring and treatment of affected women.

Keywords: immune cells, pregnancy, late-onset preeclampsia, early-onset preeclampsia, preeclampsia, inflammation, innate immunity 


\section{INTRODUCTION}

Preeclampsia accounts for over 70,000 maternal and 500,000 fetal/neonatal deaths annually, with maternal deaths being highest in developing countries $(1,2)$. The exact etiology of preeclampsia is unknown, however, endothelial dysfunction, inappropriate angiogenesis, inadequate trophoblast invasion and spiral uterine artery remodeling, have all been identified as key contributors (3-6). Adequate remodeling of spiral uterine arteries into dilated, elastic, and low-resistance blood vessels enables unlimited supplies of oxygen and nutrients to the fetus. This requires appropriate invasion by extravillous trophoblasts and replacement of maternal endothelial cells (7). Inappropriate activation of the innate immune system and subsequent inflammation, however, can lead to placental dysfunction or poor maternal vascular adaptation and contribute to the development of preeclampsia (8). In this review, we will outline mechanisms of key innate immune cells implicated in the development of preeclampsia and differentiate how these mechanisms are affected in two phenotypes of preeclampsia, early-onset preeclampsia (EOPE) and late-onset preeclampsia (LOPE). The 2018 recommendations from The International Society for the Study of Hypertension in Pregnancy (ISSHP) define preeclampsia as de-novo hypertension (systolic blood pressure $>140 \mathrm{mmHg}$ and diastolic blood pressure $>90 \mathrm{mmHg}$ ) after 20 weeks of gestation, accompanied by one or more of the following features: proteinuria ( $>300 \mathrm{mg} /$ day), maternal organ dysfunction (including hepatic, renal, neurological), or hematological involvement such as thrombocytopenia, and/or uteroplacental dysfunction, such as fetal growth restriction and/or abnormal Doppler ultrasound findings of uteroplacental blood flow (1, 2, 9). Preeclampsia with severe features is defined as cases with blood pressure values $\geq 160 / 110$ $\mathrm{mmHg}$, accompanied by significant proteinuria $(\geq 300 \mathrm{mg}$ of protein/day), or pulmonary edema, cerebrovascular and/or liver function deterioration or thrombocytopenia (10). EOPE is diagnosed before 34 weeks of gestation whereas LOPE is diagnosed from 34 weeks of gestation (2).

\section{INCIDENCE AND TREATMENT OF PREECLAMPSIA}

A systematic review of the incidence of hypertensive disorders of pregnancy, including 39 million women from 40 countries, found that preeclampsia affects $\sim 4.6 \%$ of all deliveries globally (11). Another review reported that preeclampsia complicates 2 to $8 \%$ of pregnancies (12). The reasons for differences in the incidence of preeclampsia among different countries, regions or hospitals include inconsistencies in the diagnostic criteria, difficulty in diagnosing preeclampsia, as well as differences in maternal age and nulliparity, access to prenatal care and education, and regional prevalence of other risk factors (2, $11,13)$. Women who have chronic hypertension, autoimmune disorders, kidney disease, pre-gestational diabetes, maternal body mass index $(\mathrm{BMI})>30 \mathrm{~kg} / \mathrm{m}^{2}$ and a family or personal history of preeclampsia, are at higher risk of developing preeclampsia; older age ( $>40$ years) is also associated with increased risk of preeclampsia (1). Treatment of preeclampsia can be divided into expectant care and interventionist care (14). Expectant care involves a balance of stabilizing the mother's condition and delaying delivery as far as the maternal condition allows, to reduce the mortality and morbidity associated with premature birth. Interventionist care involves early delivery to minimize serious maternal and fetal complications. Expectant care provides relief from symptoms, such as reducing blood pressure with antihypertensive therapy and the use of magnesium sulfate as anticonvulsant therapy $(2,15,16)$. Evidence suggests that there is no clear difference between an expectant or interventionist care approach for preeclampsia with severe features (14). Without a clear contraindication, delaying delivery for as long as possible can improve outcomes for the fetus (17). Studies investigating the prophylactic use of aspirin in high-risk pregnancies have reported conflicting findings $(9,18)$. A meta-analysis including 18,907 women concluded that when taken before 16 weeks of gestation at a daily dose of $\geq 100 \mathrm{mg}$, aspirin could reduce the risk of preterm preeclampsia diagnosed before 37 weeks of gestation (19). As such, high-risk patients must be identified early in pregnancy for any beneficial effects to be observed (16). Calcium supplementation for women with low calcium diets may lead to a reduction in the severity of symptoms associated with preeclampsia and minimize the risk of preterm birth $(2,18)$. In the case of diabetic pregnancies, women who were given metformin with and without insulin treatment had a lower incidence of preeclampsia (20).

\section{SIMILARITIES AND DIFFERENCES BETWEEN EARLY-ONSET AND LATE-ONSET PREECLAMPSIA}

Gestational age has been identified as the most important clinical variable in predicting both maternal and perinatal outcomes (21). This led to stratification of preeclampsia into two phenotypes, EOPE and LOPE $(1,2,22)$. LOPE accounts for the majority of preeclampsia cases, comprising 80 to $95 \%$ of all preeclampsia cases worldwide (23). EOPE, although less common, is associated with higher rates of neonatal mortality and a greater degree of maternal morbidity compared to LOPE (3). As a result, EOPE has attracted greater interest and more studies have focused on elucidating the mechanisms underlying this disease phenotype (23), leading to implementation of preventative treatments (e.g., aspirin) and predictive biomarkers more suited for EOPE than LOPE. LOPE, nevertheless, is also a serious condition, associated with a high prevalence of eclampsia and HELLP (hemolysis, elevated liver enzymes, and low platelets) syndrome, which are two life-threatening complications (24). Further studies are needed to address this gap in research. Preeclampsia has been described as a two-stage disease, with initial deficient remodeling of the uterine spiral arteries leading to a stage of maternal systemic inflammation and vascular dysfunction (25). This model is more representative of EOPE. Impaired placental development in early pregnancy and subsequent growth restriction is often 
associated with EOPE, while LOPE is likely associated with maternal endothelial dysfunction (26). Both phenotypes exhibit an increased inflammatory response that leads to adverse maternal and fetal complications. Syncytiotrophoblast stress and placental hypoxia are implicated as the main cause of excessive systemic vascular inflammation. In EOPE, this is triggered by dysfunctional perfusion of the placenta. In the case of LOPE, syncytiotrophoblast stress likely occurs as a result of compression of placental terminal villi, as the placenta outgrows the space within the uterine cavity, which can also lead to uteroplacental malperfusion $(24,27)$.

Timely detection of preeclampsia is complicated by the fact that the disease is usually asymptomatic in its early stages (2). Close antenatal monitoring, especially during the third trimester, can be crucial in preventing maternal and fetal complications. Detection using angiogenesis-related biomarkers such as the ratio of soluble fms-like tyrosine kinase-1 (sFlt-1) and placental growth factor (PIGF), as well as Doppler ultrasound assessment, can be useful in detecting EOPE, and to a lesser extent LOPE. Recently, other angiogenesisrelated biomarkers, FKBPL and CD44, were also implicated in prediction and diagnosis of preeclampsia, particularly LOPE (28). Further research is needed to elucidate the pathogenic mechanisms and develop diagnostic biomarkers for LOPE early in pregnancy, allowing interventions to begin before clinical features manifest.

\section{COMPLICATIONS ASSOCIATED WITH PREECLAMPSIA}

Women with a history of preeclampsia, in addition to short-term complications, have a higher risk of subsequent cardiovascular and metabolic disorders, especially following EOPE (29). A meta-analysis including datasets from 3,488,160 women found that women with previous preeclampsia were twice as likely to develop ischemic heart disease compared to normotensive pregnancies (30). It is not clear whether this increased risk of subsequent cardiovascular disease is caused by underlying maternal risk factors, which are exacerbated by preeclampsia, or if this increased risk is a consequence of preeclampsia (2). Potential overlapping mechanisms between preeclampsia and cardiovascular disease including hypertension and/or heart failure with preserved ejection fraction were recently identified using a bioinformatics "in silico" approach $(31,32)$.

Untreated preeclampsia, regardless of the phenotype, can result in severe complications including liver rupture, cerebral hemorrhage, myocardial infarction, stroke, acute respiratory distress syndrome, pulmonary edema, kidney failure, and abruptio placentae $(1,9,16)$. Delivery of the baby, even if it is preterm, minimizes the risk of developing these maternal and fetal complications, including fetal growth restriction and fetal loss. Premature birth, nevertheless, is also associated with a number of neonatal complications such as respiratory distress syndrome, intraventricular hemorrhage, and necrotizing enterocolitis (14). While there are a multitude of factors that contribute to the pathogenesis and onset of preeclampsia, in recent years, it has been highlighted that an overactive maternal immune system can play a critical role in preeclampsia development.

\section{INNATE IMMUNE SYSTEM IN HEALTHY PREGNANCY AND PREECLAMPSIA}

The maternal innate immune system throughout the entire gestation period plays an important role in ensuring protection from pathogens, while concurrently inducing tolerance to the semi-allogeneic developing fetus and placental development. As outlined in Figure 1, this is achieved through a delicate balance of various cell functions and interactions between the innate immune system cells and other placental/uterine cells in a timely manner $(33,34)$. Unfortunately, this is not always the case and due to various factors, the aforementioned balance is disrupted by maladaptation of certain immune cells during gestation, which is demonstrated in Figure 2. In physiological pregnancies, decidual macrophages found in proximity to spiral uterine arteries help prepare these for remodeling via secretion of angiogenic molecules (35-37). Macrophages also phagocytize apoptotic cells during tissue remodeling, preventing the release of self-antigens or paternal alloantigens, which could trigger a maternal immunological response (38). There are two phenotypes of macrophages, M1 or classically activated macrophages, and M2 or alternatively activated macrophages. M1 macrophages are involved in phagocytosis, and are micro-biocidal and pro-inflammatory. M2 macrophages are immunomodulatory and responsible for inducing maternal tolerance, resolving inflammation, and are involved in tissue remodeling and cell proliferation $(39,40)$. Therefore, in normal physiological pregnancy, macrophages favor the M2 phenotype, whereas in preeclampsia, this balance is shifted toward the M1 phenotype (41). M1 cells secrete soluble fms-like tyrosine kinase-1 (sFlt-1), an anti-angiogenic molecule that is associated with impaired angiogenesis in preeclampsia (42). Consequently, the transition of macrophage phenotype from M2 to M1 is indicative of a pro-inflammatory response as observed in preeclampsia.

\section{IMMUNOMODULATION BY INNATE IMMUNE CELLS}

Innate immune cells, while assisting in the initial stages of pregnancy, also exhibit immunomodulatory characteristics targeted at immunological responses toward the fetus. Mast cells have demonstrated such characteristics through the release of histamine and stimulation of the $G$ protein-coupled receptors $\left(\mathrm{H}_{1-4} \mathrm{R}\right)$ (43). Activation of the $\mathrm{H}_{4} \mathrm{R}$ appears to lead to proliferation of regulatory $\mathrm{T}$ cells (Tregs), and $\mathrm{H}_{2} \mathrm{R}$ support angiogenesis at the fetal-maternal interface $(43,44)$. Tregs subsequently act to prevent lymphocytes from attacking the fetus. There is limited evidence regarding the behavior of mast cells during preeclampsia and their contribution to its onset. There are some reports that they accumulate at higher density adjacent to 


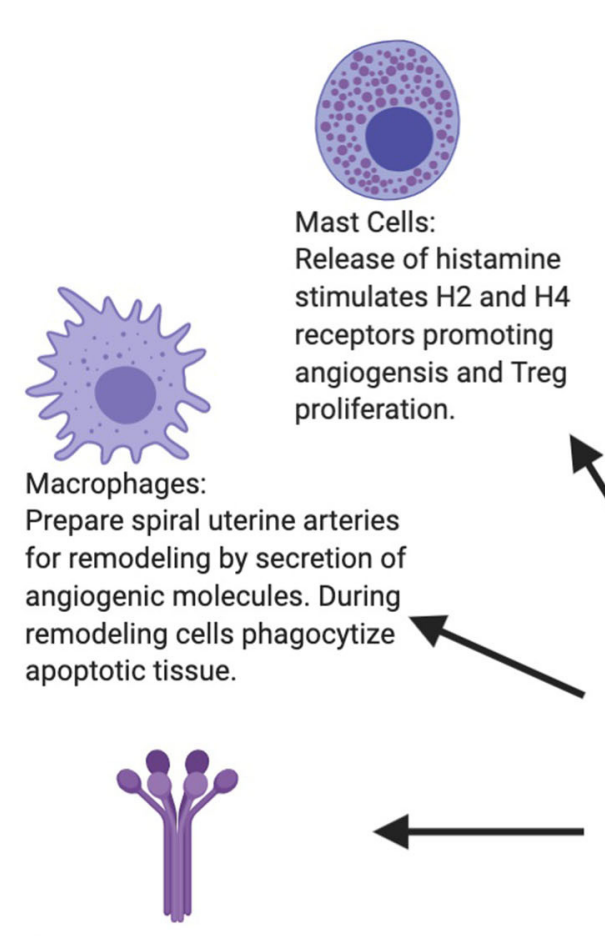

Complement System:

DAF, MCP, CD59 molecules on the surface of trophoblasts degrade convertases and inactivate components.

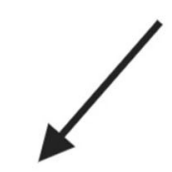

Neutrophils:

Induce tolerogenic shift in CD4+

$T$ cells via FOX01 when exposed

to local progesterone and estriol.

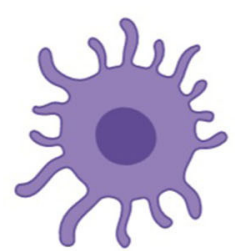

Dendritic Cells: Incomplete activation of cells by GM-CSF. Reduced ability to present antigens.
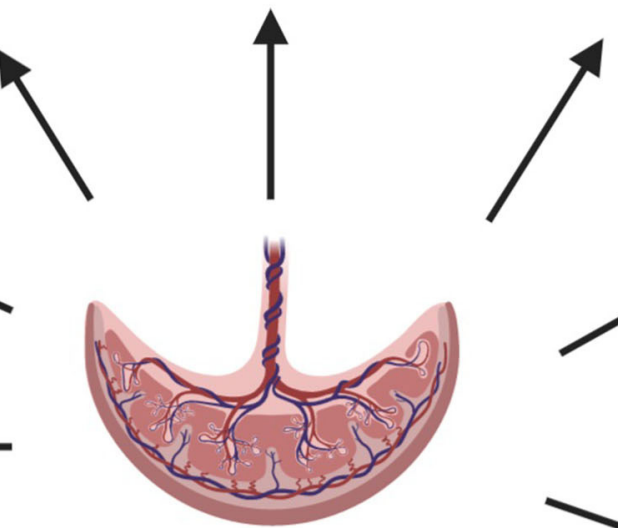

Physiological Pregnancy

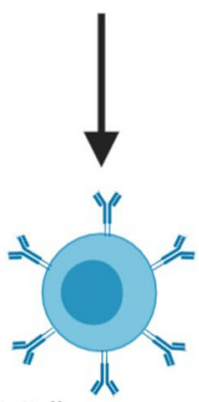

Innate B1 Cells:

B-1b cells secrete antibodies to protect the mother from pathogens. B-1a cells secrete natural IgM antibodies, helping to direct clearance of apoptotic tissue.

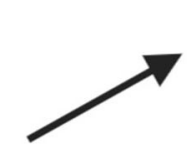

Natural Killer Cells:

Prevent cytotoxicity directed towards trophoblasts. Cells release IFN-y stimulating Treg proliferation.
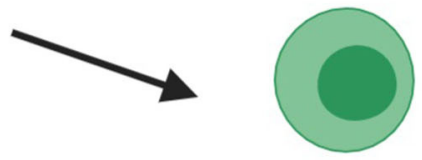

yठ T Cells:

Secrete IL-10 that stimulates proliferation of trophoblasts and suppresses apoptosis.

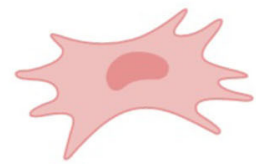

Mesenchymal Stem/Stromal Cells: Interfere with proinflammatory responses in $\mathrm{B} / \mathrm{T}$ lymphocytes, dendritic and natural killer cells. Promote IL-4 production transitioning T-helper cells to Th2.

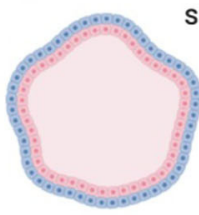

Syncytiotrophoblasts:

Produce hCG ensuring appropriate placentation and release extracellular vesicles that bind to and modulate the behaviour of $B$ cells and monocytes.

FIGURE 1 | Figure summarizes the various roles displayed by the innate and other key immune system cells as well as syncytiotrophoblasts and mesenchymal stem cells in normal physiological pregnancy. CD59+, Cluster of differentiation 59+; DAF, Decay-accelerating factor; FOXO1, Forkhead box protein-1; GM-CSF, Granulocyte-macrophage colony-stimulating factor; hCG, Human chorionic gonadotropin; IFN- $\gamma$, Interferon-gamma; IL-4, Interleukin-4; IL-10, Interleukin-10; MCP, Membrane cofactor protein.

spiral uterine arteries during preeclampsia and undergo intensive degranulation, leading to a release of large concentrations of histamines (45). The high histamine concentrations in the circulation stimulate pro-inflammatory responses from both the innate and adaptive immune system, leading to the secretion of pro-inflammatory cytokines and molecules, contributing to the increase in blood pressure, typical of preeclampsia (46).

\section{THE ROLE OF NEUTROPHILS IN MATERNAL TOLERANCE DURING PREGNANCY}

Neutrophils, also as part of a normal physiological pregnancy, are recruited to the developing placenta via the chemokine, IL-8 (47). Following the recruitment of circulating neutrophils 


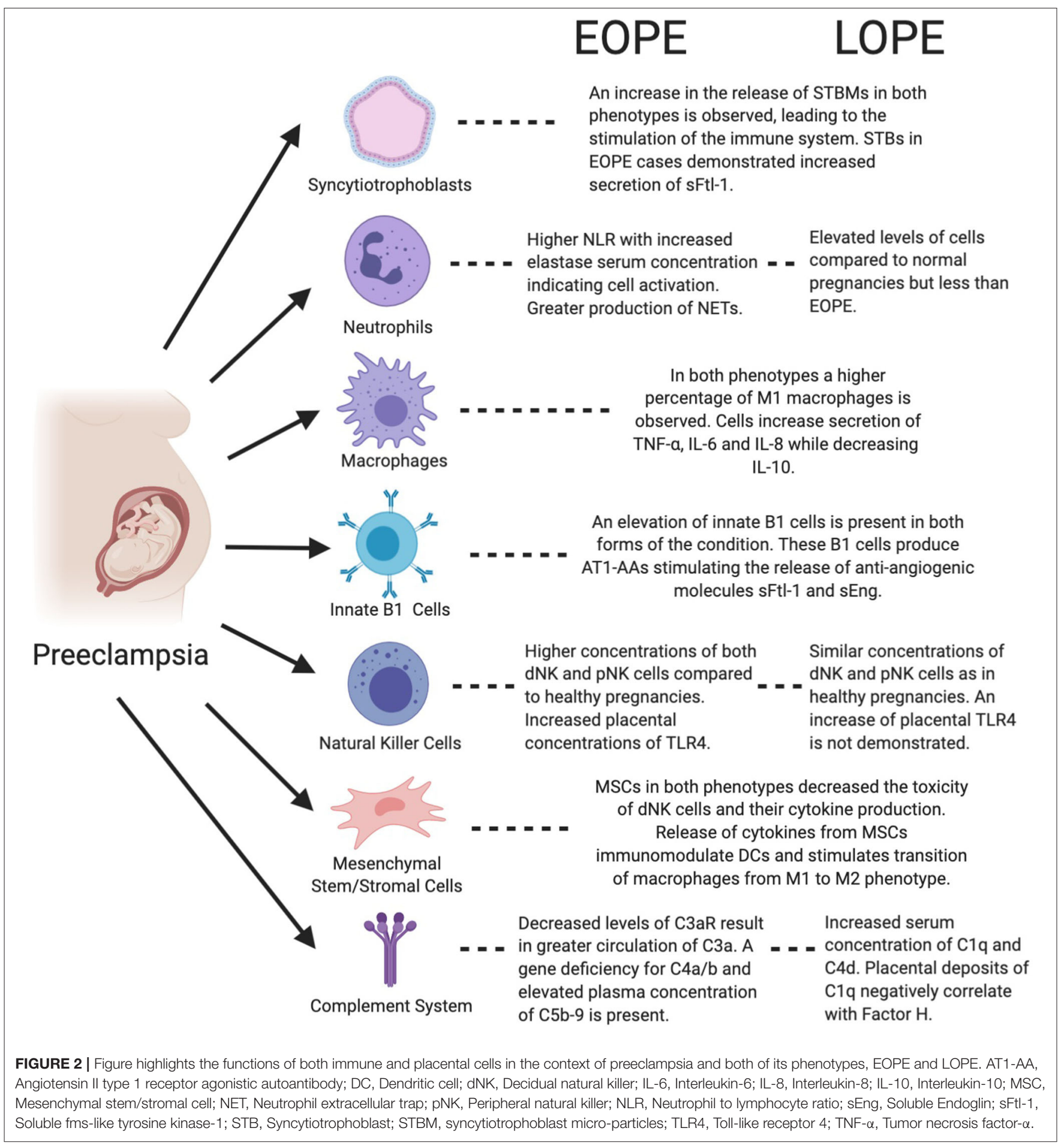

to the placenta and under the influence of progesterone and estriol, $\mathrm{CD} 4^{+} \mathrm{T}$ cells undergo immunomodulation via transfer of the forkhead box protein 1 (FOXO1) from neutrophils (48). These neutrophil-induced $\mathrm{T}$ (niT) cells, in addition to establishing maternal tolerance of the fetus, secrete IL-10, IL-17, and vascular endothelial growth factor (VEGF) promoting angiogenic processes (48). Also in normal physiological pregnancy, the natural cytotoxicity receptors (NCRs) on maternal decidual natural killer (NK) cells are inactivated to ensure maternal tolerance. This is not the case in preeclampsia due to abnormalities in the NCR structure, which increases their synthesis and expression on NK cells, thus affecting maternal tolerance to the fetus (49). Overactivation of NCRs on NK cells leads to discharge of 
pro-inflammatory cytokines, thus contributing to weakened immunological tolerance potentially endangering the fetus (50).

\section{INACTIVATION OF INNATE IMMUNE CELLS IN PREGNANCY}

Whereas the aforementioned cells either assist in required gestational processes or exhibit immunoregulatory roles, other innate immune cells become partially or fully inactivated during pregnancy. NK cells within the uterus and decidua, for example, maintain their immunological function against infections without compromising the fetus. This is achieved by inhibiting NK cell-mediated cytotoxicity toward trophoblasts by interfering with their degranulation process (51). NK cells additionally release IFN- $\gamma$, which stimulates decidual $\mathrm{CD}_{14}{ }^{+}$myelomonocytic cells to induce Treg proliferation via transforming growth factor-beta (TGF- $\beta$ ) (52). The incomplete activation of DCs by granulocyte-macrophage colonystimulating factor (GM-CSF) similarly leads to a reduction in the capacity of these cells to adequately present antigens (53). This effect consequently limits the development and activation of $\mathrm{T}$ cells, increasing maternal tolerance toward the fetus (54). DCs located proximally to the placenta remain inactivated or immature during normal pregnancy; however, these cells become inappropriately stimulated during preeclampsia. Although GMCSF initially acts as a regulator of DCs, in higher concentrations, GM-CSF along with lnc-DC (long non-coding RNA expressed in DCs), induces DC maturation $(55,56)$. Once mature, DCs can more efficiently present antigens leading to an increase in the proliferation of Th1/Th17 cells $(56,57)$. The Th1/Th17 cells consequently stimulate pro-inflammatory responses, which significantly reduce maternal tolerance.

\section{B1 CELL ACTIVATION IN HEALTHY PREGNANCY AND PREECLAMPSIA}

B1 cells, despite originating from the lymphoid group of immune cells, also belong to the innate immune system and are important in the initiation and maintenance of a healthy pregnancy. The $\mathrm{B} 1$ cell population is subdivided into two groups, $\mathrm{B}-1 \mathrm{a}$ and $\mathrm{B}-1 \mathrm{~b}$, each exhibiting unique roles throughout gestation (58). B-1b cells produce typical antibodies in response to antigen identification, providing protection against invading pathogens (58). On the other hand, B-1a cells secrete "natural IgM antibodies" with lowaffinity, poly-reactivity, and self-reactivity, regardless of antigenic stimuli $(58,59)$. These natural antibodies assist in the clearance of apoptotic tissue cell bodies, affecting the immune response during tissue remodeling (59). B1 innate cells, similar to other immune cells, are irregularly activated in preeclampsia. Notably, B-1a cells are stimulated to produce angiotensin II type 1 receptor agonistic autoantibodies (AT1-AA) in preeclampsia, which does not occur in normal physiological pregnancies (60). These antibodies, as the name suggests, act as agonists and induce signaling pathways, leading to the vasoconstriction of blood vessels and the secretion of aldosterone, which stimulates the renin-angiotensin system and increases blood pressure (61).

\section{INFLUENCE OF THE COMPLEMENT SYSTEM}

The capacity of the complement system during healthy physiological pregnancy is also modulated to prevent its activation, which could endanger the fetus. Regulatory proteins including decay-accelerating factor (DAF), membrane cofactor protein (MCP), and $\mathrm{CD} 59$, found on the surface membrane of trophoblasts, help to degrade convertases within the complement system inducing components of this system into their inactive forms by way of cleavage (62). Due to the widespread dysregulation of the maternal immune system during preeclampsia, the complement system becomes overstimulated as part of a compensatory mechanism. Over-activation of both the classical and lectin complement pathways leads to greater terminal activation, causing inflammation and the recruitment of large numbers of phagocytes to the origin of the stimuli (63). This subsequently contributes to the onset of maternal hypertension and organ damage (63).

\section{SYNCYTIOTROPHOBLAST CELLS AND THEIR SECRETED EXTRACELLULAR VESICLES}

The blastocyst, in anticipation of implantation, initiates secretion of human chorionic gonadotropin (hCG) before its synthesis is superseded by syncytiotrophoblast cells (STBs) (7). The continued secretion of hCG by STBs ensures appropriate invasion of trophoblast cells into the endometrium. Upon shedding of the STB layer, extracellular vesicles (EVs) are released from apoptotic STBs, which bind to monocytes and B cells (64). EVs encompass three main vesicle types: exosomes, microparticles/micro-vesicles and apoptotic bodies (65-67). These EVs, upon binding, induce a shift in the cytokine secretion profile of the neighboring cells, causing the release of anti-inflammatory cytokines (64). On the other hand, in preeclampsia when placental ischemia and hypoxia are present, a greater number of the STB cells undergo apoptosis (68). There is subsequently an increase in secreted EVs into the maternal circulation, overwhelming the body's ability to adequately scavenge and clear them effectively $(68,69)$. These vesicles then act as antigenic stimuli for components of the immune system leading to unintended endothelial injury, inflammation, and hypercoagulation (68).

\section{IMMUNOMODULATION BY MESENCHYMAL STEM/STROMAL CELLS}

Emerging evidence suggest that mesenchymal stem/stromal cells (MSCs) also have important immunomodulatory roles in pregnancy. Facilitated by paracrine signaling, MSCs target B/T lymphocytes, DCs, and NK cells and interfere with their pro-inflammatory responses. Simultaneously, MSCs stimulate the shift of T-helper cells from a Th1 to Th2 phenotype by promoting IL- 4 production and inhibiting IFN- $\gamma$ production, thus heightening maternal immunological tolerance of the fetus. 
Furthermore, MSCs have also been shown to have a key proangiogenic role in pregnancy (70). In preeclampsia, the function of MSCs is likely impaired due to exposure to increased numbers of reactive oxygen species (ROS) $(70,71)$. The presence of aldehyde dehydrogenases (ALDH) during normal pregnancy assists in detoxification from ROS, thus providing a degree of protection against oxidative damage (71). However, due to an unknown mechanism, levels of ALDH in preeclampsia are decreased, exposing the MSCs to oxidative stress with resulting damage and reduced functional ability to modulate other immune cells (71).

In summary, immune cells are critical in the progression of normal physiological pregnancy, both in terms of maternal tolerance and placental development; the roles of key innate and other immunogenic cells in normal physiological pregnancy are depicted in Figure 1. The vast majority of immune cells and other associated placental/uterine cells become over-activated or dysregulated in preeclampsia, contributing to the overall symptoms and features of the condition, including hypertension and organ damage.

\section{MACROPHAGE PHENOTYPE PLASTICITY IN PREECLAMPSIA}

Macrophages can alter their phenotypic profiles in response to a variety of environmental factors (39). M1 macrophages develop in response to exposure to Th1 cytokines such as IFN- $\gamma$, tumor necrosis factor (TNF)- $\alpha$ and lipopolysaccharide (LPS) $(72,73)$. The development of M2 macrophages is favored in the presence of TGF- $\beta$, IL-4, IL-10, and IL-13. Inflammatory cytokines, TNF$\alpha$, IL-6, and IL-8, are significantly increased in preeclampsia, and IL-10 is significantly decreased compared to normal pregnancy, therefore promoting the M1 phenotype $(74,75)$. Decidual macrophages comprise $20 \%$ of the immune cells present within the placenta (76). Placental decidual macrophages in normal pregnancy are mainly of the M2 subset and can be found near spiral uterine arteries (40). They have an important role in preparing spiral uterine arteries for remodeling by trophoblasts, as well as phagocytozing pro-inflammatory substances formed during the process of remodeling. The predominance of the M1 decidual macrophage phenotype is conducive to the release of substances such as TNF- $\alpha$, IFN-y and nitric oxide (NO), which inhibit trophoblast invasion and spiral uterine artery remodeling $(39,72,76)$. Various studies have reported increased levels of decidual macrophages in preeclampsia $(55,77,78)$. Other studies have reported a reduction in macrophages in the placental decidua in preeclampsia, possibly due to reduced monocyte migration to the decidua or lack of differentiation into macrophages $(79,80)$. Chitinase-3-like protein 1 (CHI3L1), also known as YKL-40, is indicative of the number of macrophages, and it has been shown to be present in significantly lower levels in women who developed EOPE compared to normal pregnancy (81). These conflicting findings may be a result of different macrophage cell markers, methods employed, use of tissue samples from different preeclampsia phenotypes and different sections of the placenta being studied, considering that decidual macrophages reside predominantly around spiral uterine arteries (82).

\section{MARKERS OF SYSTEMIC INFLAMMATION: NEUTROPHIL EXTRACELLULAR TRAPS AND THE NEUTROPHIL-LYMPHOCYTE RATIO}

Neutrophils are likely the main class of leukocytes that cause the majority of vascular cell dysfunction in women with preeclampsia (83). Neutrophil activation may occur from exposure to oxidized lipids secreted by the placenta as a consequence of placental damage. Activated neutrophils infiltrate the maternal systemic vasculature and release substances such as ROS, TNF- $\alpha$ and myeloperoxidase (MPO), causing endothelial dysfunction $(74,83)$. MPO has been associated with hypertension, and elevation in TNF- $\alpha$ is recognized as a driving inflammatory mechanisms to preeclampsia (84, 85).

Neutrophil numbers in the maternal systemic circulation and within the decidua steadily increase in pregnancy throughout gestation, yet this increase is further amplified in preeclampsia ( 4 , $74,86-88)$. Elevation in neutrophil count has been noted in both EOPE and LOPE compared to normal pregnancy, with a greater elevation present in EOPE (26). This surge in neutrophils may be an adverse reaction to the interaction between the maternal immune system and micro-debris originating from the placenta (89). Although the number of neutrophil granulocytes increases, the phagocytic function of these cells reportedly decreases in pregnancy, particularly in preeclampsia (88). Plasma elastase, a marker of neutrophil activation, has been noted to be elevated in preeclampsia when compared to normal pregnancy (90). A small sample cohort study reported a significant increase in plasma elastase in EOPE compared to normotensive controls (3). Neutrophil extracellular traps (NETs) have been found in the intervillous spaces of placentae in women with preeclampsia (25). The formation of these web-like chromatin structures is induced by STB microparticles (STBMs) released from the placenta and ROS (91). Neutrophils, in addition to causing inflammation, represent the first wave of leukocytes responding to inflammation $(5,83)$. NETs are abundant within sites of inflammation causing endothelial damage as demonstrated in cases of sepsis, and may also cause damage to villous trophoblast cells in preeclampsia $(92,93)$. The presence of NETs in the maternal circulation during pregnancy can contribute to thrombotic events, inflammation, and ultimately, fetal death (94). The neutrophil-to-lymphocyte ratio (NLR), is a measure of systemic inflammation, and has demonstrated prognostic value in several cardiovascular diseases, including preeclampsia (4). Both normal pregnancy and preeclampsia present with an increased NLR compared to non-pregnant controls (95). Several studies, however, have reported the NLR to be significantly higher in women with preeclampsia compared to normotensive controls $(6,16,96,97)$. A retrospective case-control study conducted with 186 patients found the NLR to be highest in EOPE, and LOPE demonstrating higher NLRs compared to normotensive controls (26). A change 
in the NLR can be noted at 16-18 weeks of gestation, and thus has a potential as an inexpensive biomarker for the early detection, monitoring and prompt intervention particularly for EOPE (97).

\section{NATURAL KILLER CELLS IN PREECLAMPSIA}

As discussed previously, in normal pregnancy the appropriate remodeling of spiral uterine arteries into low resistance and high capacity vessels coordinated with appropriate trophoblast invasion is pivotal. When these two processes are not wellcoordinated, the consequent insufficient blood flow leads to a series of events, which ultimately result in the development of preeclampsia. This suggests that interactions at the maternalfetal interface in early gestation are important for determining the course of pregnancy. In order to preserve an adequate immuno-tolerant environment, DCs and T-lymphocytes have limited access to the decidua during pregnancy (98). NK cells, in fact, represent $70 \%$ of the immune cells in the decidua (99, 100). These decidual NK (dNK) cells are a distinct population from peripheral NK ( $\mathrm{pNK}$ ), both phenotypically and functionally. Unlike $\mathrm{pNK}$, the $\mathrm{dNK}$ subpopulation has a $\mathrm{CD} 56^{+} / \mathrm{CD} 16^{-}$phenotype (101) and demonstrates a lower cytotoxic potential and higher cytokine secretory profile (102). Decidual NK cells, by secreting VEGF and PlGF, stimulate spiral uterine artery remodeling, a process crucial for successful establishment of the placenta and the feto-maternal interface in pregnancy $(103,104)$. The lack of dNK cells has been shown to lead to lower fertility and higher fetal resorption (105). NK cells, on the other hand, are recruited by the innate immune system in response to inadequate trophoblast invasion or insufficient spiral uterine artery remodeling, processes observed in preeclampsia. There are some inconsistencies among studies, however, with respect to the number of these cells present in preeclampsia compared to normotensive pregnancy. While some studies have reported significantly lower numbers of $\mathrm{NK} \mathrm{CD56}{ }^{+}$cells within the decidua in preeclampsia (77, 106), other reports have indicated the opposite trend (107, 108). The heterogeneity among studies and the differences in patient characteristics offer possible explanations for these discrepancies. A recent study demonstrated that the increases in both $\mathrm{dNK}$ and pNK cells were higher in EOPE compared to LOPE (108).

\section{TOLL-LIKE RECEPTORS IN PREECLAMPSIA}

Toll-like receptors (TLRs) represent a family of transmembrane signaling receptors found on all innate immune cells. Ten different TLRs have been identified in humans based on their cellular localization and respective ligands (109). All 10 TLRs activate nuclear factor $\kappa \mathrm{B}-(\mathrm{NF}-\kappa \mathrm{B})$ dependent and NF- $\kappa \mathrm{B}$ independent pathways to generate cytokines and chemokines (109). TLR expressions vary throughout pregnancy. Trophoblast expression of TLRs changes throughout gestation, with TLR2-4 being highly expressed during the first trimester and TLR1-10 in the third trimester (110-114). TLRs activate inflammatory responses by recognizing damage-associated molecular patterns (DAMPs) released following tissue injury, as well as pathogenassociated molecular patterns (PAMPs) specific to microbial components (115-117). Continuous signaling from DAMPs due to persistent cell death and remodeling of spiral uterine arteries leads to over-activation of TLRs. Excessive TLR activity may contribute to the pro-inflammatory effects and hypertension observed in preeclampsia. Studies report that overstimulation of these receptors due to either viral or bacterial infections may lead to adverse pregnancy outcomes including preeclampsia (114, 118). Upon trophoblast TLR-3 and TLR-4 activation by microbial byproducts, chemokine secretion initiates the innate immune response and the decidua becomes infiltrated with pNK cells and macrophages (113). TLR4 activation by bacterial LPS, in addition, inhibits trophoblast migration (119), while TLR3 activation by poly I:C, a double-stranded RNA (dsRNA) viral mimetic, increases inflammation and results in the development of preeclampsia-like symptoms in pregnant rats (120). Increased immunoreactivity of the TLR4 protein in placentae from complicated pregnancies suggests that their role in the activation of the innate immune system is in response to the presence of infectious agents (112). It has been recently shown that the expression of TLR4 in placentae from women with EOPE was higher than TLR4 expression in women with LOPE (121). It is possible that this upregulation is part of a compensatory mechanism in preeclampsia, given that higher expression of TLR4 has been described in human term placentae compared to first trimester (122). Activation of TLR3 in pregnant mice increased systolic blood pressure and endothelial damage, both of which were further exacerbated in the absence of IL-10 (123). Moreover, dsRNA and singlestranded RNA (ssRNA) were shown to upregulate expressions of TLR3, TLR7, and TLR8 in mouse placentae. This caused pregnancy-dependent hypertension, endothelial dysfunction, and placental inflammation (124). Women with preeclampsia displayed activation of the aforementioned TLRs; however the association between severity of the disease and activation of TLRs was not confirmed (124). Increased expression of TLR9 in the placentae and peripheral blood mononuclear cells from women with preeclampsia compared to normotensive controls has also been described $(125,126)$. A study by He et al. showed that when mice were treated with a TLR9 agonist, they developed preeclampsia-like symptoms. This preeclampsia murine model also showed that with exogenous overexpression of TLR9, the levels of sFlt-1 increased while VEGF was downregulated. This suggests that TLR9 is capable of suppressing angiogenesis (127) and that aberrantly activated ligand binding to different TLRs may significantly influence pregnancy outcomes. In a relatively recent study, it was demonstrated that inhibition of TLR activation and thus inhibition of downstream signaling, could not prevent embryo resorption in the absence of dNK cells $(105,128)$. Differential expressions of TLRs throughout pregnancy and in preeclampsia, suggest that these receptors might represent potential therapeutic targets. 


\section{THE ROLE OF INNATE B1 CELLS IN PREECLAMPSIA}

As indicated above, there are two different subsets of B1 cells. $\mathrm{B} 1 \mathrm{a}$ cells are $\mathrm{CD}^{+}$and produce "natural antibodies," which are polyreactive, low-affinity and self-reactive antibodies. On the other hand, B1b cells are $\mathrm{CD}^{-}$and produce adaptive antibodies when exposed to antigens (58). It is, however, the role of B1a cells that is more closely associated with adverse pregnancy outcomes. Namely, the proportion of B1a cells decreases throughout gestation likely as a protective mechanism against poly-reactive antibodies produced by B1 these cells, which recognize and target a variety of antigens including fetal antigens (129). Their role in preeclampsia has not fully been investigated. However, there are studies emerging regarding their association with hypertensive disorders in pregnancy. The number of peripheral blood B1a cells in women with preeclampsia is significantly increased compared to normal pregnant women (60), however no difference in their number between severe and mild preeclampsia has been observed (130). In addition to the well-established Th1/Th2/Th17-Treg paradigm of the pathogenesis of preeclampsia [as reviewed in (131)], the role of B1 cells is likely linked to stimulation of $\mathrm{CD} 4^{+}$ $\mathrm{T}$ cells and their differentiation into Th17 effector cells (132). It has also been demonstrated that B1a cells can produce agonistic autoantibodies to AT1-AA in pregnancy, which can lead to the development of preeclampsia (133). High affinity binding of AT1-AA to receptors within the placenta leads to increased secretion of anti-angiogenic factors (sFlt-1 and Endoglin), both of which are associated with the onset of preeclampsia (134136). These autoantibodies appear to correlate with severity of preeclampsia (137). The depletion of B-cells in an animal model of preeclampsia resulted in a decrease in the level of AT1AA and a reduction in preeclampsia symptoms (138). Natural antibodies secreted by B1a cells are mostly IgM antibodies and are important in clearing and neutralizing pro-inflammatory targets (139). Although the specific roles of B1 cells have not been elucidated yet, their numbers were not significantly increased following placental ischemia (140). Substantial depletion of B cells by the monoclonal anti-human CD20 antibody, rituximab, interestingly did not have a significant effect on the hypertensive response in the RUPP model (140).

In summary, only a limited number of studies have assessed the role of innate B1 cells in preeclampsia. Further research is needed to evaluate the association of innate B1 cells with hypertensive disorders in pregnancy, as well as their role and pathogenic mechanisms in EOPE vs. LOPE.

\section{EMERGING ROLE OF $\mathrm{\delta} \delta$ T CELLS IN PREECLAMPSIA}

Within the decidua, $\mathrm{x} \delta \mathrm{T}$ cells despite originating from the lymphoid lineage facilitate proliferation of trophoblast cells while concurrently suppressing their apoptosis through the secretion of IL-10 (141, 142). This ensures adequate migration and invasion of trophoblast cells leading to appropriate placental development. The role of $\gamma \delta \mathrm{T}$ cells has not yet been determined in preeclampsia, but increases in the production of proinflammatory stimuli, interferon (IFN)- $\gamma$ \& IL-17, by $\gamma \delta \mathrm{T}$ cells have been reported in women with idiopathic recurrent pregnancy loss (143). Furthermore, in mice, a competitive antagonist binding of the histocompatibility complex (MHC) class II found on the surface of $\mathrm{\gamma} \delta \mathrm{T}$ cells, resulted in the reduction of their immunological capabilities (144). The $\mathrm{x} \delta$ $\mathrm{T}$ cell "knockout mice" displayed a resistance to developing preeclampsia-like features, implying that these cells could have a role in the pathogenesis of the condition (144). In the same study, preeclamptic placentae demonstrated significantly increased levels of $\gamma \delta$ T cells (144).

\section{THE DYSREGULATION AND OVER-ACTIVATION OF THE COMPLEMENT SYSTEM DURING PREECLAMPSIA}

The distribution and activity of the complement system's components vary between EOPE and LOPE, likely stemming from their different underlying pathogeneses. Dysfunction related to the complement system in EOPE has been correlated with single nucleotide polymorphisms (SNPs) as demonstrated by Wu et al. (145). More specifically, C6 (rs7444800, rs4957381) and MASP1 (rs1108450, rs3774282, rs698106) polymorphisms were shown to correspond independently to a risk of EOPE and severe preeclampsia (145). Another modification to the complement system that is unique to EOPE is the reduction in the placental concentrations of complement $3 a$ receptor $(\mathrm{C} 3 \mathrm{aR})$ mRNA and protein (146). These reductions lead to an increase in the plasma concentration of $\mathrm{C} 3 \mathrm{a}$, the ligand for this receptor (146). Lokki et al. expanded upon these findings and compared the activation of the complement pathways in EOPE vs. normal pregnancies. In their cohort study of 22 women, those with EOPE displayed higher placental deposition of C1q, specifically proximal to areas of fibrinoid necrosis (147). They demonstrated that $43 \%$ of EOPE cases had a gene deficiency for $\mathrm{C} 4 \mathrm{a} / \mathrm{b}$, a deficiency known to also be implicated in certain autoimmune disorders (147). Finally, Lokki et al. noted that areas of C3b deposition were positively correlated with $\mathrm{C} 1 \mathrm{q}$ and negatively with Factor $\mathrm{H}$, a regulatory factor of the alternative pathway (147). The over-activation of the complement system in EOPE is reinforced by the rise in the plasma concentration of C5b9, which is indicative of terminal activation (148). C-reactive proteins of the system, specifically, C3a, have also been found circulating in high concentration within the amniotic fluid in EOPE (149).

LOPE shares many characteristics with EOPE in dysregulation of the complement system, with some key distinctions. As in EOPE, the MASP1 gene has been shown to display SNPs, however, in LOPE the variants indicated are rs1357134 and rs698090 (145). The aforementioned variations in the genes are completely different from the ones detected in EOPE cases and are specifically correlated with LOPE (145). Examining the sera of both EOPE and LOPE, severe preeclampsia cases revealed some degree of activation of the complement system, as demonstrated by Jia et al. (150). Serum levels of C1q, Factor H, C3 and C4 
significantly decreased, while the $\mathrm{Bb}$ concentration increased in the presence of either EOPE or LOPE compared to their respective controls (150). Despite this, the concentrations of the C-reactive proteins observed in LOPE were not significantly different than in the EOPE cohort (150). Nevertheless, another recent study by $\mathrm{He}$ et al. using similar sample size, characterized the components of the complement system using plasma samples from 30 EOPE and 30 LOPE patients with severe preeclampsia. The results obtained contradicted Jia's investigation, showing elevated $\mathrm{Bb}, \mathrm{C} 3 \mathrm{a}, \mathrm{C} 5 \mathrm{a}$, and MAC in both EOPE and LOPE, whereas LOPE was specifically associated with elevated C1q and C4d compared to normotensive controls (151). Lokki et al. built upon this data, by inspecting the dissimilarities of $\mathrm{C1q}$ deposition in the STB layer of the placenta of LOPE patients. This investigation revealed that the $\mathrm{C} 1 \mathrm{q}$ deposits negatively correlated with Factor $\mathrm{H}$, characterizing a shift toward activation within the complement system (147).

\section{SYNCYTIOTROPHOBLASTS PLAY IMPORTANT ROLE IN PREECLAMPSIA}

STBs form the feto-maternal placental barrier, which separates the fetal and maternal circulations (65). The STB-containing layer, as described above, is shed into the maternal circulation by the placenta during normal pregnancy, releasing STBMs $(152,153)$. STBMs levels were increased in EOPE compared to matched normal pregnancies, whereas no change was observed between LOPE and normal pregnancy samples (154). This increase in STMBs potentially contributes to endothelial dysfunction and systemic inflammation (155). Another study confirmed no significant difference between levels of EVs from various cells including STBs, in normal pregnancy compared to LOPE (156). Further studies are needed to determine whether this shedding is potentially more prominent in EOPE compared to LOPE. STBM shedding has been linked to increased levels of active tissue factor, leading to enhanced aggregation of platelets (157). This is evident in EOPE with severe features, but not observed in LOPE, which supports evidence suggesting two distinct phenotypic pathogeneses. Further studies are needed to explore if higher levels of STBMs in EOPE are due to their prevalence being greater in early gestation, independent of the presence of preeclampsia (153). STBMs act as ligands for receptors, growth and coagulation factors, and RNA molecules, and have an important role in cell-cell communication (65). STBMs bind TLRs and activate monocytes, DCs, NK cells, and neutrophils. The subsequent release of various inflammatory cytokines and superoxide radicals contributes to the systemic inflammation associated with preeclampsia $(74,88,94,158)$.

The release of sFlt-1 from STBs exerts indirect anti-angiogenic effects by competitively blocking binding of VEGF and PIGF to their respective receptors $(158,159)$. Levels of sFlt-1 are increased in preeclampsia and can be used as a biomarker of STB stress associated with EOPE $(67,158)$. LOPE does not present with this early pathology, with studies reporting changes in angiogenic biomarkers near term, observing similar plasma concentrations in both normal pregnancies and LOPE, thus not providing reliable detection of LOPE (160). Contrary to findings describing the prominent role of STBMs, it has been suggested that soluble factors directly released from STBs mediate endothelial dysfunction in preeclampsia rather than EVs (161).

\section{MSC REGULATION OF INNATE IMMUNE SYSTEM RESPONSE IS IMPAIRED IN PREECLAMPSIA}

Increased attention has been directed toward investigating the role of MSCs and their immunomodulatory capacity during pregnancy and its complications. As their potential therapeutic role in preeclampsia has been discussed elsewhere $(70,162$, 163), here we discuss their contribution to irregular innate immune system signaling in preeclampsia. MSCs are found in many tissues, such as bone marrow, and adipose, decidual and fetal tissue (164-166). Adipose-derived MSCs have demonstrated impaired function associated with senescence in women with preeclampsia (167). Decidual MSCs mediate appropriate placentation and ensure immune tolerance to the semi-allograft fetus $(168,169)$. These decidual MSCs have the ability to decrease NK cell cytotoxicity and cytokine production (170). This may potentiate the transition of peripheral into decidual NK cells, a process critical for adequate decidual function. Decidual MSCs in addition regulate $\mathrm{dNK}$ through their intracellular cytokine expression profile, including TNF- $\alpha$ and IL-4 and via the interaction between collagen and LAIR-1 (171). Bone marrowderived MSCs are also capable of modulating NK cells by inhibiting their proliferation, cytokine secretion, and cytotoxicity against HLA-class I- expressing targets, either via soluble factors or via cell-to-cell specific interactions (172, 173). A study by Aggarwal and Pittenger showed that immunosuppressive MSC features are associated with the inhibition of TNF- $\alpha$ and IFN- $\gamma$, and the secretion of prostaglandin $E_{2}$ (PGE2) $(174,175)$. Notably, it has been previously suggested that the lack of this prostaglandin in preeclampsia leads to a decrease in both renal blood flow and sodium excretion (176). The immunomodulatory interactions between MSCs and NK cells, along with existing studies, provide promising results that strengthen the potential immunomodulatory effects of MSCs. Although MSC are considered privileged immune cells, they can be recognized and eliminated by activated NK cells (172).

Human placental MSCs also have an immunoregulatory effect on macrophage differentiation, favoring the expression of the M2-immunosuppressive phenotype (177). This immunoregulatory effect may be mediated by soluble molecules acting partially via glucocorticoid and progesterone receptors. MSC treatment decreases IL- 6 and TNF- $\alpha$, while increasing anti-inflammatory cytokine, IL-10 (178). A previous study has suggested that PGE2 plays an important role in the immunoregulatory effects of MSC, indicating that M2 macrophage polarization is initiated via the COX-2-PGE2 pathway $(178,179)$. MSCs are the most widely used stem cellbased therapies due to their beneficial immunomodulation, antioxidant, pro-angiogenic, and regenerative therapeutic effects. Their therapeutic potential for the prevention and treatment of 
TABLE 1 | Therapeutic strategies targeting aberrant innate immune system mechanisms implicated in preeclampsia

\begin{tabular}{|c|c|c|}
\hline Innate immunity target & Treatment & Mechanism \\
\hline Macrophages & $\begin{array}{l}\text { Salidroside (SLDS) is a phenylpropanoid } \\
\text { glycoside extracted from the root of } \\
\text { Rhodiola rosea } L\end{array}$ & $\begin{array}{l}\text { Reduction in M1 macrophage/microglia polarization and an } \\
\text { increase in M2 macrophage/microglia polarization in mice }\end{array}$ \\
\hline Macrophages & Macrophages transplantation & Increase in M2-polarized macrophages \\
\hline Neutrophils & $\begin{array}{l}\text { Maternal corticosteroid administration- } \\
\text { Betamethasone }\end{array}$ & $\begin{array}{l}\text { Reversal of delayed neutrophil apoptosis (returning the } \\
\text { normal rate of spontaneous neutrophil apoptosis) }\end{array}$ \\
\hline STBM & $\begin{array}{l}\text { Neprilysin (NEP) inhibitors } \\
\text { Racecadotril (Hidrasec®) }\end{array}$ & $\begin{array}{l}\text { Inhibition of STBM released, promoting vasodilatation, and } \\
\text { natriuresis }\end{array}$ \\
\hline Maternal microbiome & $\begin{array}{l}\text { Probiotic-rich food } \\
\text { Milk-based probiotics e.g., Lactobacillus } \\
\text { acidophilus and Lactobacillus rhamnosus }\end{array}$ & $\begin{array}{l}\text { Consumption of probiotic-rich food during pregnancy has } \\
\text { been associated with lower rates of preterm birth and } \\
\text { preeclampsia } \\
\text { Probiotics have been implicated in the modification of } \\
\text { placental trophoblast inflammation, systemic inflammation, } \\
\text { and blood pressure, all features of preeclampsia } \\
\text { Lactobacillus could be associated with lower risk of } \\
\text { preeclampsia in primiparous women } \\
\text { Overstimulation of the innate immune system due to dysbiosis } \\
\text { of the maternal microbiome has been linked to preeclampsia }\end{array}$ \\
\hline IL-10 & Recombinant Human Interleukin-10 & Increased anti-inflammatory capacity \\
\hline
\end{tabular}

Infliximab

Complement system

TLR9

TLR2 \& TLR4

TLR4

TLR9

TLR4

TLR4/NF-kB pathway
Ravulizumab

(Ultomiris $\circledast$ )

TLR9 antagonist Low-dose naltrexone (LDN)

Sparstolonin B (SsnB) derived from the Chinese herb Spaganium stoloniferum Ibudilast

TLR9 inhibitory oligodinucleotide (ODN2088)

Berberine- isoquinoline alkaloid mainly extracted from Rhizoma Coptidis

Parthenolide- Feverfew (Tanacetum parthenium L.)
TNF $\alpha$ antagonist

Anti-inflammatory effects

\section{Safety in pregnancy}

References

Unknown

$(73,181)$

Risk for fetal and maternal micro-chimerism

Betamethasone acetate Category C (TGA)

Betamethasone dipropionate

Category B1 (TGA)

Category B1 (FASS)

Generally recognized as safe (GRAS) by FDA

(185-188)

No significant effect on fetal development in mice

Reduced inflammatory activity (studied in Crohn's disease)

Blocks TLR2- and TLR4-mediated NFKB activation in mouse Anti-angiogenic and anti-estrogen toxicity effects in macrophages induced by LPS and Pam3CSK4

Upregulation of anti-inflammatory cytokines (IL-10, IL-4) Antagonism of TLR4

Antagonism of TLR9 associated with reduction in systolic blood pressure

\section{LPS antagonist}

Inhibition of LPS/TLR4 signaling

Inhibition of the TLR4/NF-KB pathway
Recombinant IL-10 reverses hypoxia-induced effects in pregnant mice

Category B (FDA)

No increases in miscarriage, structural neonatal malformations or prematurity were observed

compared with non-exposed pregnancies

Category B2 (FASS)

Category B3 (FASS)

(194-196) pregnant rodents

Not tested in pregnant women

No adverse effects were observed in mice receiving this treatment in a model of type 1 diabetes mellitus ODN2088-treated mice gave birth to healthy pups

(189-191)

$(85,192)$

Berberine can cause or worsen jaundice in newborn infants and could lead to kernicterus

Not safe in pregnancy

Feverfew (Tanacetum parthenium L.) shows

potential emmenagogue activity and

induces abortion www.clinicaltrials.gov (NCT01389193)

(199-201)

(202-206)

$(202,207,208)$ 


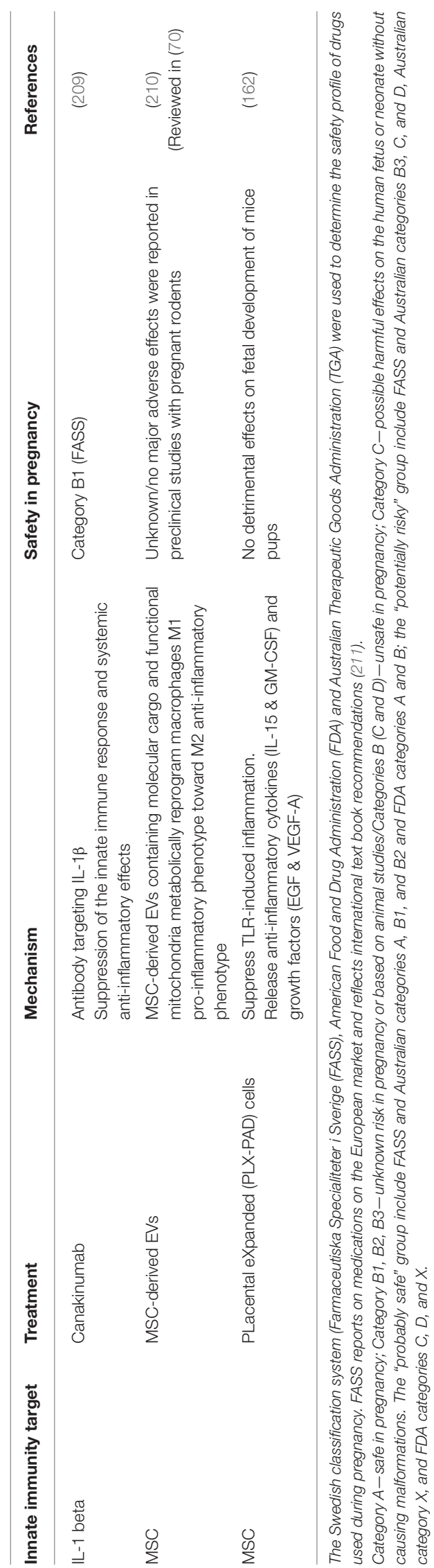

preeclampsia is emerging from a number of pre-clinical studies, which show the ability of MSCs and their associated EVs to abrogate symptoms and features of preeclampsia (reviewed in (70). Their relevance specifically to EOPE and LOPE needs to be elucidated further.

\section{THERAPEUTIC STRATEGIES FOR TARGETING INNATE IMMUNE SYSTEM ABERRANT MECHANISMS AS POTENTIAL TREATMENTS FOR PREECLAMPSIA}

Finding potential novel treatments for preeclampsia is an area of unmet clinical need and is inherently challenging. Significant knowledge gaps exist surrounding the safety, effectiveness and long-term effects of drugs for the use in pregnancy (180). Clinical trials investigating therapeutics that could be potentially repurposed for preeclampsia often have pregnancy as an exclusion criterion because of possible teratogenic risks or other harmful effects to the fetus (Table 1). Consequently, phase 2 or 3 trial data in pregnancy are generally lacking, making it difficult to inform novel treatment strategies. Physiological changes occur in nearly all organs during pregnancy and the pharmacokinetics and pharmacodynamics of drugs are often significantly altered, although the specific changes are mostly undetermined (212). New micro-physiological systems technology such as "Organ on a chip" models may in the future be used to help fill these gaps in knowledge (213).

Dysregulation of TLRs and detection of host-derived DAMPs contribute to the pathogenesis of preeclampsia, as described above (214). Novel TLR antagonists, especially inhibitors of TLR4 and TLR9, have potential as exciting new therapeutic agents for inflammatory disorders. The anti-inflammatory properties of TLR antagonists have been explored in numerous clinical trials for diseases such as systemic lupus erythematosus, infection-associated sepsis and vascular disorders such as hypertension (194), yet it is unknown if these agents are safe to use in pregnancy. This is a research area that therefore warrants further investigation perhaps in pre-clinical models of preeclampsia. Many of the aforementioned immune cells have similar unexplored potential and are presented in Table 1. The understanding of the role of the innate immune system in the multifactorial pathogenesis of preeclampsia has been significantly advanced. This progress makes novel therapeutic strategies for targeting aberrant mechanisms within the innate immune system possible as potential treatments for preeclampsia. To support this advancement, greater research capacity and robust and safe clinical trials with pregnant women are needed, with particular focus on delineating differences in EOPE and LOPE management. Anti-inflammatory and immunomodulatory drugs used for other diseases may not be appropriate and safe to use in preeclampsia. It is important to rule out drugs that are not suitable for repurposing in order to streamline future research strategies to focus on more viable alternatives. 


\section{DISCUSSION}

There is a plethora of evidence supporting the role of the maternal innate immune system in the pathogenesis of preeclampsia. Mechanisms of irregular signaling and function of the innate immune cells could be explored as potential biomarkers or therapeutic targets in preeclampsia. Moreover, these cells appear to play different roles in the two phenotypes of preeclampsia, EOPE and LOPE, which could lead to better risk stratification and personalized management of preeclampsia. Developing reliable predictive and diagnostic biomarkers especially for LOPE has been challenging given that preeclampsia is a multifactorial disease with a poorly understood pathogenesis (215). As depicted in this review, there are a number of different cell types, both from the innate immune system and other supportive systems such as MSCs and STBs, which if exhibiting irregular signaling, can lead to the development of EOPE or LOPE, or both (Figure 2).

While in some cases quantifying a particular cell types could be utilized as a biomarker of the disease, such as the number of innate B1 cells or NK cells (both pNK and dNK), the mechanisms involved are often diverse and therefore a panel of biomarkers would be necessary to accurately predict or diagnose preeclampsia. Given that the two phenotypes of preeclampsia are often not considered and distinguished in research, it is encouraging that in terms of the innate immune system, there is important evidence emerging regarding the influence of the innate immune system in both EOPE and LOPE. For example, both $\mathrm{dNK}$ and pNK cells, as well as TLR4, are likely increased in EOPE, whereas in LOPE there does not appear to be a difference in these factors compared to healthy pregnancy. Another frequently observed difference between EOPE and LOPE is the proliferation of neutrophils and neutrophil associated processes, with increases in NLR, elastase and NETs being much higher in EOPE than in LOPE. Macrophages and innate B1 cells, on the other hand, do not seem to be dysregulated differently between EOPE and LOPE.

Despite the emergence of novel research highlighting the differences in the behavior of certain innate immune cells in terms of the pathogenesis of EOPE and LOPE, it is important to acknowledge that given the complexity of this condition, there are often inter-personal variations in both the mechanisms and symptoms of the disease. Consequently, these factors impose further difficulties in monitoring, diagnosis, and treatment of preeclampsia. In light of this, it is not surprising that there is a lack of effective treatment strategies for this devastating pregnancy condition. A holistic approach to disease monitoring is necessary to identify women at high risk of developing preeclampsia in conjunction with determining a panel of biomarkers representative of the multifactorial nature and different phenotypes of this disease.

Our evaluation of the existing literature describing interactions between maternal innate immune cells and cells of placental/uterine origin identified a number of limitations in the field. As the heterogeneous nature of preeclampsia has only been recently classified, there is a delay in current research, with a limited number of studies fully examining the interplay among innate immune cells and components of the placenta in the context of both EOPE and LOPE. Certain cell types, nevertheless, have been well-characterized for these two phenotypes of preeclampsia. Evidence is lacking, however, for other cell types of the innate immune system regarding their involvement in the pathogenesis of preeclampsia regardless of the phenotype. These include eosinophils, basophils, mast cells, DCs, and Langerhans cells. It is possible that some of these do not play an important role in the development of preeclampsia. However, given the key roles of mast cells and DCs in pregnancy (Figure 1) and some evidence of their roles in the placental bed in preeclampsia, albeit with conflicting results (40), it is likely that these cells could influence preeclampsia monitoring and treatment in the future. A portion of the reviewed literature did examine the various cell types discussed above, however, evidence was provided regarding their behavior in cases of mild and severe preeclampsia, rather than EOPE and LOPE. As a consequence, while there is currently some literature reporting on the behavior of innate immune cell types in preeclampsia, more substantial evidence is required to accurately distinguish immune cell behaviors in both phenotypes of the condition.

Carrying out research with vulnerable groups such as pregnant women is inherently challenging and results in certain limitations. Adherence to stringent ethical considerations and difficulty in obtaining early placental tissue reduces the ability of an investigation to fully elucidate the roles that the immune cells may play in the pathogenesis of preeclampsia. Recent developments in a number of microfluidics or 3D multicellular platforms may greatly increase our understanding of the cellular and molecular mechanisms of the innate immune system associated with inadequate remodeling of spiral uterine arteries or placental development/growth relevant to preeclampsia. The DAX-1 ${ }^{\mathrm{TM}}$ chip manufactured by AIM Biotechnology has been demonstrated to successfully and accurately recapitulate human tumor immune microenvironments (216). Utilizing this microfluidics platform, investigators were able to examine cell type dependent interactions and provide a novel insight into the tumor immune responses (216). Utilization of these or similar platforms might be able to reproduce the multicellular autocrine and paracrine conditions of preeclampsia, and the behavior of innate immune cells within the microenvironment could be further studied. Thus, researchers can circumnavigate the hurdles of collecting early pregnancy placental tissue while still producing accurate and relevant data. Replicating an EOPE or LOPE environment will be challenging given the distinct and overlapping features of these two phenotypes of preeclampsia. Nevertheless, additional benefits of the microfluidics platforms include the ability to track molecular changes in real-time and the potential to test emerging drug treatments.

\section{CONCLUSION}

Components of the innate immune system are fully or partially inactivated, or experience a tolerogenic shift in 
their immunological function throughout gestation. This, in conjunction with the ability of certain placental cells to modulate the immune system, confers a level of protection to the developing fetus against detrimental immunological responses. This delicate balance is disrupted in preeclampsia, leading to the inappropriate over-activation of these immune cells, causing disruption of appropriate placentation and contributing to the development of this hypertensive condition with end-organ damage. Although the dysfunction of these cells is observed in LOPE, the imbalance appears to be most pronounced in EOPE. While existing literature provides some evidence regarding the roles of the innate immune cells, including NK cells and neutrophils in EOPE and LOPE, further investigation specifically

\section{REFERENCES}

1. Brown MA, Magee LA, Kenny LC, Karumanchi SA, McCarthy FP, Saito S, et al. Hypertensive disorders of pregnancy: ISSHP classification, diagnosis, and management recommendations for international practice. Hypertension. (2018) 72:24-43. doi: 10.1161/HYPERTENSIONAHA.117.10803

2. Burton GJ, Redman CW, Roberts JM, Moffett A. Pre-eclampsia: pathophysiology and clinical implications. BMJ. (2019) 366:12381. doi: $10.1136 / \mathrm{bmj} .12381$

3. Gupta AK, Gebhardt S, Hillermann R, Holzgreve W, Hahn S. Analysis of plasma elastase levels in early and late onset preeclampsia. Arch Gynecol Obstet. (2006) 273:239-42. doi: 10.1007/s00404-005-0093-z

4. Oylumlu M, Ozler A, Yildiz A, Oylumlu M, Acet H, Polat N, et al. New inflammatory markers in pre-eclampsia: echocardiographic epicardial fat thickness and neutrophil to lymphocyte ratio. Clin Exp Hypertens. (2014) 36:503-7. doi: 10.3109/10641963.2013.863324

5. Gezer C, Ekin A, Ertas IE, Ozeren M, Solmaz U, Mat E, et al. High firsttrimester neutrophil-to-lymphocyte and platelet-to-lymphocyte ratios are indicators for early diagnosis of preeclampsia. Ginekol Pol. (2016) 87:431-5. doi: 10.5603/GP.2016.0021

6. Gogoi P, Sinha P, Gupta B, Firmal P, Rajaram S. Neutrophil-to-lymphocyte ratio and platelet indices in pre-eclampsia. Int J Gynaecol Obstet. (2019) 144:16-20. doi: 10.1002/ijgo.12701

7. McNally R, Alqudah A, Obradovic D, McClements L. Elucidating the pathogenesis of pre-eclampsia using in vitro models of spiral uterine artery remodelling. Curr Hypertens Rep. (2017) 19:93. doi: 10.1007/s11906-017-0786-2

8. Pierik E, Prins JR, van Goor H, Dekker GA, Daha MR, Seelen MAJ, et al. Dysregulation of complement activation and placental dysfunction: a potential target to treat preeclampsia? Front Immunol. (2019) 10:3098. doi: 10.3389/fimmu.2019.03098

9. Mol BWJ, Roberts CT, Thangaratinam S, Magee LA, de Groot CJM, Hofmeyr GJ. Pre-eclampsia. Lancet. (2016) 387:999-1011. doi: 10.1016/S0140-6736(15)00070-7

10. Mihu D, Razvan C, Malutan A, Mihaela C. Evaluation of maternal systemic inflammatory response in preeclampsia. Taiwan J Obstet Gynecol. (2015) 54:160-6. doi: 10.1016/j.tjog.2014.03.006

11. Abalos E, Cuesta C, Grosso AL, Chou D, Say L. Global and regional estimates of preeclampsia and eclampsia: a systematic review. Eur J Obstet Gynecol Reprod Biol. (2013) 170:1-7. doi: 10.1016/j.ejogrb.2013.05.005

12. Duley L. The global impact of pre-eclampsia and eclampsia. Semin Perinatol. (2009) 33:130-7. doi: 10.1053/j.semperi.2009.02.010

13. Schindler AE. New data about preeclampsia: some possibilities of prevention. Gynecol Endocrinol. (2018) 34:636-7. doi: 10.1080/09513590.2018.1441401

14. Churchill D, Duley L, Thornton JG, Moussa M, Ali HS, Walker KF. Interventionist versus expectant care for severe pre-eclampsia between 24 and 34 weeks' gestation. Cochrane Database Syst Rev. (2018) 10:CD003106. doi: 10.1002/14651858.CD003106.pub3 in the context of both phenotypes of preeclampsia, is required to address knowledge gaps. This could lead to the identification of specific disease mechanisms, which could be explored as new diagnostic biomarkers or treatment targets, hence improving the management of preeclampsia and identifying potential emerging treatments for both EOPE and LOPE.

\section{AUTHOR CONTRIBUTIONS}

IA, SS, and DP carried out literature search and created a draft of the manuscript. LM, VG, and TS conceptualized the topic, supervised, and revised the draft. All authors approved the manuscript.

15. Heil SG, Herzog EM, Griffioen PH, van Zelst B, Willemsen SP, de Rijke $\mathrm{YB}$, et al. Lower S-adenosylmethionine levels and DNA hypomethylation of placental growth factor (PlGF) in placental tissue of early-onset preeclampsia-complicated pregnancies. PLoS ONE. (2019) 14:e0226969. doi: 10.1371/journal.pone.0226969

16. Mannaerts D, Heyvaert S, De Cordt C, Macken C, Loos C, Jacquemyn Y. Are neutrophil/lymphocyte ratio (NLR), platelet/lymphocyte ratio (PLR), and/or mean platelet volume (MPV) clinically useful as predictive parameters for preeclampsia? J Matern Fetal Neonatal Med. (2019) 32:14129. doi: 10.1080/14767058.2017.1410701

17. Sato Y, Moriuchi K, Sakae-Matsumoto C, Ueda M, Fujita K. Factors contributing to favourable neonatal outcomes in early-onset severe preeclampsia. J Obstet Gynaecol.(2020) 1-6. doi: 10.1080/01443615.2019.1706160

18. Tskhay V, Schindler A, Shestakova M, Klimova O, Narkevich Capital AC The role of progestogen supplementation (dydrogesterone) in the prevention of preeclampsia. Gynecol Endocrinol. (2019) 36:698-701. doi: 10.1080/09513590.2019.1706085

19. Roberge S, Bujold E, Nicolaides KH. Aspirin for the prevention of preterm and term preeclampsia: systematic review and meta-analysis. Am J Obstet Gynecol. (2018) 218:287-93 e281. doi: 10.1016/j.ajog.2017.11.561

20. Alqudah A, McKinley MC, McNally R, Graham U, Watson CJ, Lyons TJ, et al. Risk of pre-eclampsia in women taking metformin: a systematic review and meta-analysis. Diabet Med. (2018) 35:160-72. doi: 10.1111/dme.13523

21. Von Dadelszen P, Magee LA, Roberts JM. Subclassification of preeclampsia. Hypertens Pregnancy. (2003) 22:143-8. doi: 10.1081/PRG-120021060

22. Bouter AR, Duvekot JJ. Evaluation of the clinical impact of the revised ISSHP and ACOG definitions on preeclampsia. Pregnancy Hypertens. (2020) 19:206-11. doi: 10.1016/j.preghy.2019.11.011

23. Huppertz B. The critical role of abnormal trophoblast development in the etiology of preeclampsia. Curr Pharm Biotechnol. (2018) 19:771-80. doi: 10.2174/1389201019666180427110547

24. Staff AC. The two-stage placental model of preeclampsia: an update. J Reprod Immunol. (2019) 134-5:1-10. doi: 10.1016/j.jri.2019.07.004

25. Gardiner C, Vatish M. Impact of haemostatic mechanisms on pathophysiology of preeclampsia. Thromb Res. (2017) 151(Suppl. 1):S48-52. doi: 10.1016/S0049-3848(17)30067-1

26. Orgul G, Aydin Hakli D, Ozten G, Fadiloglu E, Tanacan A, Beksac MS. First trimester complete blood cell indices in early and late onset preeclampsia. Turk J Obstet Gynecol. (2019) 16:112-7. doi: 10.4274/tjod.galenos.2019. 93708

27. Redman CW, Sargent IL, Staff AC. IFPA Senior Award Lecture: making sense of pre-eclampsia - two placental causes of preeclampsia? Placenta. (2014) 35(Suppl.):S20-5. doi: 10.1016/j.placenta.2013.12.008

28. Todd N, McNally R, Alqudah A, Jerotic DJ, Suvakov S, Obradovic D, et al. Role of a novel angiogenesis FKBPL-CD44 pathway in preeclampsia risk stratification and mesenchymal stem cell treatment. JCEM. (2020). doi: 10.1210/clinem/dgaa403. [Epub ahead of print]. 
29. Phipps E, Prasanna D, Brima W, Jim B. Preeclampsia: updates in pathogenesis, definitions, and guidelines. Clin J Am Soc Nephrol. (2016) 11:1102-13. doi: 10.2215/CJN.12081115

30. Bellamy L, Casas JP, Hingorani AD, Williams DJ. Pre-eclampsia and risk of cardiovascular disease and cancer in later life: systematic review and meta-analysis. BMJ. (2007) 335:974. doi: 10.1136/bmj.39335.385301.BE

31. Suvakov S, Bonner E, NikolicV, JeroticDJ, Simic TP, GarovicVD, et al. Overlapping pathogenic signallingpathways and biomarkers in preeclampsia and cardiovascular disease. Pregnancy Hypertens. (2020) 20:131-6. doi: 10.1016/j.preghy.2020.03.011.263-5

32. Lopez-Campos G, Bonner E, McClements L. An integrative biomedical informatics approach to elucidate the similarities between preeclampsia and hypertension. Stud Health Technol Inform. (2019) 264:988-92. doi: 10.3233/SHTI190372

33. Mor G, and Cardenas I. The immune system in pregnancy: a unique complexity. Am J Reprod Immunol. (2010) 63:425-33. doi: 10.1111/j.1600-0897.2010.00836.x

34. Bonney EA. Immune regulation in pregnancy: a matter of perspective? Obstetr Gynecol Clin. (2016) 43:679-98. doi: 10.1016/j.ogc.2016.07.004

35. Al-khafaji LA, Al-Yawer MA. Localization and counting of CD68-labelled macrophages in placentas of normal and preeclamptic women. In: AIP Conference Proceedings. Erbil: AIP Publishing LLC (2017). p. 020012.

36. Owen JL, Mohamadzadeh M. Macrophages and chemokines as mediators of angiogenesis. Front Physiol. (2013) 4:159. doi: 10.3389/fphys.2013.00159

37. Faas MM, De Vos P. Uterine NK cells and macrophages in pregnancy. Placenta. (2017) 56:44-52. doi: 10.1016/j.placenta.2017.03.001

38. Abrahams VM, Kim YM, Straszewski SL, Romero R, Mor G. Macrophages and apoptotic cell clearance during pregnancy. Am J Reprod Immunol. (2004) 51:275-82. doi: 10.1111/j.1600-0897.2004.00156.x

39. Ning F, Liu H, Lash GE. The role of decidual macrophages during normal and pathological pregnancy. Am J Reprod Immunol. (2016) 75:298-309. doi: 10.1111/aji.12477

40. Faas MM, De Vos P. Innate immune cells in the placental bed in healthy pregnancy and preeclampsia. Placenta. (2018) 69:125-33. doi: 10.1016/j.placenta.2018.04.012

41. Faas MM, Spaans F, De Vos P. Monocytes and macrophages in pregnancy and pre-eclampsia. Front Immunol. (2014) 5:298. doi: 10.3389/fimmu.2014.00298

42. Schonkeren D, van der Hoorn M-L, Khedoe P, Swings G, van Beelen E, Claas F, et al. Differential distribution and phenotype of decidual macrophages in preeclamptic versus control pregnancies. Am J Pathol. (2011) 178:709-17. doi: 10.1016/j.ajpath.2010.10.011

43. Del Rio R, Noubade R, Saligrama N, Wall EH, Krementsov DN, Poynter $\mathrm{ME}$, et al. Histamine $\mathrm{H} 4$ receptor optimizes $\mathrm{T}$ regulatory cell frequency and facilitates anti-inflammatory responses within the central nervous system. $J$ Immunol. (2012) 188:541-7. doi: 10.4049/jimmunol.1101498

44. Woidacki K, Meyer N, Schumacher A, Goldschmidt A, Maurer M, Zenclussen AC. Transfer of regulatory $\mathrm{T}$ cells into abortion-prone mice promotes the expansion of uterine mast cells and normalizes early pregnancy angiogenesis. Sci Rep. (2015) 5:1-10. doi: 10.1038/srep13938

45. Szewczyk G, Pyzlak M, Klimkiewicz J, Smiertka W, Miedzinska-Maciejewska M, Szukiewicz D. Mast cells and histamine: do they influence placental vascular network and development in preeclampsia? Mediators Inflamm. (2012) 2012:307189. doi: 10.1155/2012/307189

46. O'Mahony L, Akdis M, Akdis CA. Regulation of the immune response and inflammation by histamine and histamine receptors. J Allergy Clin Immunol. (2011) 128:1153-62. doi: 10.1016/j.jaci.2011.06.051

47. Cemgil Arikan D, Aral M, Coskun A, Ozer A. Plasma IL-4, IL-8, IL12 , interferon- $\gamma$ and CRP levels in pregnant women with preeclampsia, and their relation with severity of disease and fetal birth weight. $J$ Matern Fetal Neonat Med. (2012) 25:1569-73. doi: 10.3109/14767058.2011. 648233

48. Nadkarni S, Smith J, Sferruzzi-Perri AN, Ledwozyw A, Kishore M, Haas R, etal. Neutrophilsinduce proangiogenic T cells with aregulatory phenotype in pregnancy. Proc Natl Acad Sci USA. (2016) 113:E8415-24. doi: 10.1073/pnas.1611944114

49. Fukui A, Funamizu A, Yokota M, Yamada K, Nakamua R, Fukuhara R, et al. Uterine and circulating natural killer cells and their roles in women with recurrent pregnancy loss, implantation failure and preeclampsia. J Reprod Immunol. (2011) 90:105-10. doi: 10.1016/j.jri.2011.04.006

50. Hashemi V, Dolati S, Hosseini A, Gharibi T, Danaii S, Yousefi M. Natural killer T cells in Preeclampsia: an updated review. Biomed Pharmacother. (2017) 95:412-8. doi: 10.1016/j.biopha.2017.08.077

51. Sun J, Yang M, Ban Y, Gao W, Song B, Wang Y, et al. Tim-3 is upregulated in NK cells during early pregnancy and inhibits NK cytotoxicity toward trophoblast in galectin-9 dependent pathway. PLoS ONE. (2016) 11:e0147186. doi: 10.1371/journal.pone.0147186

52. Vacca P, Moretta L, Moretta A, Mingari MC. Origin, phenotype and function of human natural killer cells in pregnancy. Trends Immunol. (2011) 32:51723. doi: 10.1016/j.it.2011.06.013

53. Moldenhauer LM, Keenihan SN, Hayball JD, Robertson SA. GM-CSF is an essential regulator of $\mathrm{T}$ cell activation competence in uterine dendritic cells during early pregnancy in mice. J Immunol. (2010) 185:7085-96. doi: 10.4049/jimmunol.1001374

54. Della Bella S, Giannelli S, Cozzi V, Signorelli V, Cappelletti M, Cetin $\mathrm{I}$, et al. Incomplete activation of peripheral blood dendritic cells during healthy human pregnancy. Clin Exp Immunol. (2011) 164:180-92. doi: 10.1111/j.1365-2249.2011.04330.x

55. Huang SJ, Zenclussen AC, Chen C-P, Basar M, Yang H, Arcuri F, et al. The implication of aberrant GM-CSF expression in decidual cells in the pathogenesis of preeclampsia. Am J Pathol. (2010) 177:2472-82. doi: 10.2353/ajpath.2010.091247

56. Zhang W, Zhou Y, Ding Y. Lnc-DC mediates the over-maturation of decidual dendritic cells and induces the increase in Th1 cells in preeclampsia. Am J Reprod Immunol. (2017) 77:e12647. doi: 10.1111/aji.12647

57. Wang J, Tao Y-M, Cheng X-Y, Zhu T-F, Chen Z-F, Yao H, et al. Dendritic cells derived from preeclampsia patients influence Th1/Th17 cell differentiation in vitro. Int J Clin Exp Med. (2014) 7:5303-9.

58. Muzzio D, Zenclussen AC, Jensen F. The role of B cells in pregnancy: the good and the bad. Am J Reprod Immunol. (2013) 69:408-12. doi: 10.1111/aji.12079

59. Nguyen T, Ward C, Morris J. To B or not to B cells-mediate a healthy start to life. Clin Exp Immunol. (2013) 171:124-34. doi: 10.1111/cei.12001

60. Jensen F, Wallukat G, Herse F, Budner O, El-Mousleh T, Costa S-D, et al. CD19+ CD5 + cells as indicators of preeclampsia. Hypertension. (2012) 59:861-8. doi: 10.1161/HYPERTENSIONAHA.111.188276

61. Cornelius DC, Cottrell J, Amaral LM, LaMarca B. Inflammatory mediators: a causal link to hypertension during preeclampsia. Br J Pharmacol. (2019) 176:1914-21. doi: 10.1111/bph.14466

62. Denny KJ, Woodruff TM, Taylor SM, Callaway LK. Complement in pregnancy: a delicate balance. Am J Reprod Immunol. (2013) 69:3-11. doi: 10.1111/aji.12000

63. Derzsy Z, Prohászka Z, Rigó Jr J, Füst G, Molvarec A. Activation of the complement system in normal pregnancy and preeclampsia. Mol Immunol. (2010) 47:1500-6. doi: 10.1016/j.molimm.2010.01.021

64. Southcombe J, Tannetta D, Redman C, Sargent I. The immunomodulatory role of syncytiotrophoblast microvesicles. PLoS ONE. (2011) 6:e20245. doi: 10.1371/journal.pone.0020245

65. Familari M, Cronqvist T, Masoumi Z, Hansson SR. Placenta-derived extracellular vesicles: their cargo and possible functions. Reprod Fertil Dev. (2017) 29:433-47. doi: 10.1071/RD15143

66. Tannetta D, Masliukaite I, Vatish M, Redman C, Sargent I. Update of syncytiotrophoblast derived extracellular vesicles in normal pregnancy and preeclampsia. J Reprod Immunol. (2017) 119:98-106. doi: 10.1016/j.jri.2016.08.008

67. Göhner C, Plosch T, Faas MM. Immune-modulatory effects of syncytiotrophoblast extracellular vesicles in pregnancy and preeclampsia. Placenta. (2017) 60(Suppl. 1):S41-51. doi: 10.1016/j.placenta.2017.06.004

68. Han C, Han L, Huang P, Chen Y, Wang Y, Xue F. Syncytiotrophoblast-derived extracellular vesicles in pathophysiology of preeclampsia. Front Physiol. (2019) 10:1236. doi: 10.3389/fphys.2019.01236

69. Kaminska A, Enguita FJ, Stepien EŁ. Lactadherin: an unappreciated haemostasis regulator and potential therapeutic agent. Vasc Pharmacol. (2018) 101:21-8. doi: 10.1016/j.vph.2017.11.006

70. Suvakov S, Richards C, Nikolic V, Simic T, McGrath K, Krasnodembskaya $A$, et al. Emerging therapeutic potential of mesenchymal stem/stromal 
cells in preeclampsia. Curr Hypertens Rep. (2020) 22:37-37. doi: 10.1007/s11906-020-1034-8

71. Kusuma GD, Abumaree MH, Perkins AV, Brennecke SP, Kalionis B. Reduced aldehyde dehydrogenase expression in preeclamptic decidual mesenchymal stem/stromal cells is restored by aldehyde dehydrogenase agonists. Sci Rep. (2017) 7:42397. doi: 10.1038/srep42397

72. Wheeler KC, Jena MK, Pradhan BS, Nayak N, Das S, Hsu CD, et al. VEGF may contribute to macrophage recruitment and M2 polarization in the decidua. PLoS ONE. (2018) 13:e0191040. doi: 10.1371/journal.pone.0191040

73. Wang Y, Smith W, Hao D, He B, Kong L. M1 and M2 macrophage polarization and potentially therapeutic naturally occurring compounds. Int Immunopharmacol. (2019) 70:459-66. doi: 10.1016/j.intimp.2019.02.050

74. Laresgoiti-Servitje E. A leading role for the immune system in the pathophysiology of preeclampsia. J Leukoc Biol. (2013) 94:247-57. doi: $10.1189 / \mathrm{jlb} .1112603$

75. Sharma A, Satyam A, Sharma JB. Leptin, IL-10 and inflammatory markers (TNF-alpha, IL-6 and IL-8) in pre-eclamptic, normotensive pregnant and healthy non-pregnant women. Am J Reprod Immunol. (2007) 58:21-30. doi: 10.1111/j.1600-0897.2007.00486.x

76. Li ZH, Wang LL, Liu H, Muyayalo KP, Huang XB, Mor G, et al. Galectin-9 alleviates LPS-induced preeclampsia-like impairment in rats via switching decidual macrophage polarization to M2 subtype. Front Immunol. (2018) 9:3142. doi: $10.3389 /$ fimmu. 2018.03142

77. Milosevic-Stevanovic J, Krstic M, Radovic-Janosevic D, Popovic J, Tasic M, Stojnev S. Number of decidual natural killer cells \& macrophages in pre-eclampsia. Indian J Med Res. (2016) 144:823-30. doi: 10.4103/ijmr.IJMR_776_15

78. Li M, Piao L, Chen CP, Wu X, Yeh CC, Masch R, et al. Modulation of decidual macrophage polarization by macrophage colony-stimulating factor derived from first-trimester decidual cells: implication in preeclampsia. Am J Pathol. (2016) 186:1258-66. doi: 10.1016/j.ajpath.2015.12.021

79. Bürk MR, Troeger C, Brinkhaus R, Holzgreve W, Hahn S. Severely reduced presence of tissue macrophages in the basal plate of pre-eclamptic placentae. Placenta. (2001) 22:309-16. doi: 10.1053/plac.2001.0624

80. Jena MK, Nayak N, Chen K, Nayak NR. Role of macrophages in pregnancy and related complications. Arch Immunol Ther Exp. (2019) 67:295-309. doi: 10.1007/s00005-019-00552-7

81. Kucur M, Tuten A, Oncul M, Acikgoz AS, Yuksel MA, Imamoglu $\mathrm{M}$, et al. Maternal serum apelin and YKL-40 levels in early and late-onset pre-eclampsia. Hypertens Pregnancy. (2014) 33:467-75. doi: 10.3109/10641955.2014.944709

82. Yao $\mathrm{Y}, \mathrm{Xu} \mathrm{XH}$, Jin $\mathrm{L}$. Macrophage polarization in physiological and pathological pregnancy. Front Immunol. (2019) 10:792. doi: $10.3389 /$ fimmu.2019.00792

83. Cadden KA, Walsh SW. Neutrophils, but not lymphocytes or monocytes, infiltrate maternal systemic vasculature in women with preeclampsia. Hypertens Pregnancy. (2008) 27:396-405. doi: 10.1080/10641950801958067

84. Shukla J, Walsh SW. Neutrophil release of myeloperoxidase in systemic vasculature of obese women may put them at risk for preeclampsia. Reprod Sci. (2015) 22:300-7. doi: 10.1177/1933719114557899

85. Alijotas-Reig J, Esteve-Valverde E, Ferrer-Oliveras R, Llurba E, Gris JM. Tumor necrosis factor-alpha and pregnancy: focus on biologics. An updated and comprehensive review. Clin Rev Allergy Immunol. (2017) 53:40-53. doi: 10.1007/s12016-016-8596-x

86. Lurie S, Frenkel E, Tuvbin Y. Comparison of the differential distribution of leukocytes in preeclampsia versus uncomplicated pregnancy. Gynecol Obstet Invest. (1998) 45:229-31. doi: 10.1159/000009973

87. Regal JF, Lillegard KE, Bauer AJ, Elmquist BJ, Loeks-Johnson AC, Gilbert JS. Neutrophil depletion attenuates placental ischemia-induced hypertension in the rat. PLOS ONE. (2015) 10:e0132063. doi: 10.1371/journal.pone.0132063

88. Lampe R, Kover A, Szucs S, Pal L, Arnyas E, Poka R. The effect of healthy pregnant plasma and preeclamptic plasma on the phagocytosis index of neutrophil granulocytes and monocytes of nonpregnant women. Hypertens Pregnancy. (2017) 36:59-63. doi: 10.1080/10641955.2016.1237644

89. Hahn S, Giaglis S, Hoesli I, Hasler P. Neutrophil NETs in reproduction: from infertility to preeclampsia and the possibility of fetal loss. Front Immunol. (2012) 3:362. doi: 10.3389/fimmu.2012.00362
90. Fuchisawa A, van Eeden S, Magee LA, Whalen B, Leung PC, Russell JA, et al. Neutrophil apoptosis in preeclampsia, do steroids confound the relationship? J Obstet Gynaecol Res. (2004) 30:342-8. doi: 10.1111/j.1447-0756.2004.00209.x

91. Konecna B, Laukova L, Vlkova B. Immune activation by nucleic acids: a role in pregnancy complications. Scand J Immunol. (2018) 87:e12651. doi: $10.1111 /$ sji.12651

92. Brinkmann V, Reichard U, Goosmann C, Fauler B, Uhlemann Y, Weiss DS, et al. Neutrophil extracellular traps kill bacteria. Science. (2004) 303:1532-5. doi: $10.1126 /$ science. 1092385

93. Gupta AK, Joshi MB, Philippova M, Erne P, Hasler P, Hahn S, et al. Activated endothelial cells induce neutrophil extracellular traps and are susceptible to NETosis-mediated cell death. FEBS Lett. (2010) 584:3193-7. doi: 10.1016/j.febslet.2010.06.006

94. Giaglis S, Stoikou M, Grimolizzi F, Subramanian BY, van Breda SV, Hoesli I, et al. Neutrophil migration into the placenta: good, bad or deadly? Cell Adh Migr. (2016) 10:208-25. doi: 10.1080/19336918.2016.1148866

95. Mannaerts D, Faes E, Goovaerts I, Stoop T, Cornette J, Gyselaers $\mathrm{W}$, et al. Flow-mediated dilation and peripheral arterial tonometry are disturbed in preeclampsia and reflect different aspects of endothelial function. Am J Physiol Regul Integr Comp Physiol. (2017) 313:R518-R525. doi: 10.1152/ajpregu.00514.2016

96. Serin S, Avci F, Ercan O, Kostu B, Bakacak M, Kiran H. Is neutrophil/lymphocyte ratio a useful marker to predict the severity of pre-eclampsia? Pregnancy Hypertens. (2016) 6:22-5. doi: 10.1016/j.preghy.2016.01.005

97. Panwar M, Kumari A, Hp A, Arora R, Singh V, Bansiwal R. Raised neutrophil lymphocyte ratio and serum beta hCG level in early second trimester of pregnancy as predictors for development and severity of preeclampsia. Drug Discov Ther. (2019) 13:34-7. doi: 10.5582/ddt.2019.01006

98. Nancy P, Erlebacher A. T cell behavior at the maternal-fetal interface. Int $J$ Dev Biol. (2014) 58:189-98. doi: 10.1387/ijdb.140054ae

99. King A. Uterine leukocytes and decidualization. Hum Reprod Update. (2000) 6:28-36. doi: 10.1093/humupd/6.1.28

100. Bulmer JN, Morrison L, Longfellow M, Ritson A, Pace D. Granulated lymphocytes in human endometrium: histochemical and immunohistochemical studies. Hum Reprod. (1991) 6:791-8. doi: 10.1093/oxfordjournals.humrep.a137430

101. Lanier LL, Le AM, Civin CI, Loken MR, Phillips JH. The relationship of CD16 (Leu-11) and Leu-19 (NKH-1) antigen expression on human peripheral blood NK cells and cytotoxic T lymphocytes. J Immunol. (1986) 136:4480-6.

102. Laskarin G, Tokmadzic VS, Strbo N, Bogovic T, Szekeres-Bartho J, Randic $\mathrm{L}$, et al. Progesterone induced blocking factor (PIBF) mediates progesterone induced suppression of decidual lymphocyte cytotoxicity. Am J Reprod Immunol. (2002) 48:201-9. doi: 10.1034/j.1600-0897.2002.01133.x

103. Lash GE, Schiessl B, Kirkley M, Innes BA, Cooper A, Searle RF, et al. Expression of angiogenic growth factors by uterine natural killer cells during early pregnancy. J Leukoc Biol. (2006) 80:572-80. doi: 10.1189/jlb. 0406250

104. Gibson DA, Greaves E, Critchley HO, Saunders PT. Estrogen-dependent regulation of human uterine natural killer cells promotes vascular remodelling via secretion of CCL2. Hum Reprod. (2015) 30:1290-301. doi: 10.1093/humrep/dev067

105. Wang W, Lin Y, Zeng S, Li D-J. Improvement of fertility with adoptive $\mathrm{CD} 25+$ natural killer cell transfer in subfertile nonobese diabetic mice. Reprod Biomed Online. (2009) 18:95-103. doi: 10.1016/S1472-6483(10)60430-0

106. Williams PJ, Bulmer JN, Searle RF, Innes BA, Robson SC. Altered decidual leucocyte populations in the placental bed in pre-eclampsia and foetal growth restriction: a comparison with late normal pregnancy. Reproduction. (2009) 138:177-84. doi: 10.1530/REP-09-0007

107. Bachmayer N, Rafik Hamad R, Liszka L, Bremme K, SverremarkEkstrom E. Aberrant uterine natural killer (NK)-cell expression and altered placental and serum levels of the NK-cell promoting cytokine interleukin-12 in pre-eclampsia. Am J Reprod Immunol. (2006) 56:292-301. doi: $10.1111 /$ j.1600-0897.2006.00429.x 
108. Du M, Wang W, Huang L, Guan X, Lin W, Yao J, et al. Natural killer cells in the pathogenesis of preeclampsia: a double-edged sword. J Matern Fetal Neonatal Med. (2020) 1-8. doi: 10.1080/14767058.2020.1740675

109. Takeda K, Kaisho T, Akira S. Toll-like receptors. Annu Rev Immunol. (2003) 21:335-76. doi: 10.1146/annurev.immunol.21.120601.141126

110. Holmlund U, Cebers G, Dahlfors AR, Sandstedt B, Bremme K, Ekstrom ES, et al. Expression and regulation of the pattern recognition receptors Tolllike receptor-2 and Toll-like receptor-4 in the human placenta. Immunology. (2002) 107:145-51. doi: 10.1046/j.1365-2567.2002.01491.x

111. Zarember KA, Godowski PJ. Tissue expression of human toll-like receptors and differential regulation of toll-like receptor mRNAs in leukocytes in response to microbes, their products, and cytokines. J Immunol. (2002) 168:554-51. doi: 10.4049/jimmunol.168.2.554

112. Kumazaki K, Nakayama M, Yanagihara I, Suehara N, Wada Y. Immunohistochemical distribution of Toll-like receptor 4 in term and preterm human placentas from normal and complicated pregnancy including chorioamnionitis. Hum Pathol. (2004) 35:47-54. doi: 10.1016/j.humpath.2003.08.027

113. Abrahams VM, Visintin I, Aldo PB, Guller S, Romero R, Mor G. A role for TLRs in the regulation of immune cell migration by first trimester trophoblast cells. J Immunol. (2005) 175:8096-104. doi: 10.4049/jimmunol.175.12.8096

114. Abrahams VM, Bole-Aldo P, Kim YM, Straszewski-Chavez SL, Chaiworapongsa T, Romero R, et al. Divergent trophoblast responses to bacterial products mediated by TLRs. J Immunol. (2004) 173:4286-96. doi: 10.4049/jimmunol.173.7.4286

115. Ann-Charlotte I. Inflammatory mechanisms in preeclampsia. Pregnancy Hypertens. (2013) 3:58. doi: 10.1016/j.preghy.2013.04.005

116. McCarthy CG, Goulopoulou S, Wenceslau CF, Spitler K, Matsumoto T, Webb RC. Toll-like receptors and damage-associated molecular patterns: novel links between inflammation and hypertension. Am J Physiol Heart Circ Physiol. (2014) 306:H184-96. doi: 10.1152/ajpheart.00328.2013

117. Takeda K, Akira S. Toll-like receptors. Curr Protoc Immunol. (2015) 109:14 12 11-14 12 10. doi: 10.1002/0471142735.im1412s109

118. Romero R, Chaiworapongsa T, Espinoza J. Micronutrients and intrauterine infection, preterm birth and the fetal inflammatory response syndrome. $J$ Nutr. (2003) 133(5 Suppl. 2):1668S-73S. doi: 10.1093/jn/133.5.1668S

119. Chaiworapongsa T, Romero R, Espinoza J, Kim YM, Edwin S, Bujold E, et al. Macrophage migration inhibitory factor in patients with preterm parturition and microbial invasion of the amniotic cavity. J Matern Fetal Neonatal Med. (2005) 18:405-16. doi: 10.1080/14767050500361703

120. Tinsley JH, Chiasson VL, Mahajan A, Young KJ, Mitchell BM. Toll-like receptor 3 activation during pregnancy elicits preeclampsia-like symptoms in rats. Am J Hypertens. (2009) 22:1314-9. doi: 10.1038/ajh.2009.185

121. Nizyaeva N, Kulikova G, Nagovitsyna M, Shchegolev A. Peculiarities of the expression of TLR4 and inhibitor of TLR-cascade tollip in the placenta in early and late-onset preeclampsia. Bull Exp Biol Med.(2019) 166:507-11. doi: 10.1007/s10517-019-04383-6

122. Beijar EC, Mallard C, Powell TL. Expression and subcellular localization of TLR-4 in term and first trimester human placenta. Placenta. (2006) 27:3226.doi: $10.1016 /$ j.placenta.2004.12.012

123. Chatterjee P, Chiasson VL, Kopriva SE, Young KJ, Chatterjee V, Jones $\mathrm{KA}$, et al. Interleukin 10 deficiency exacerbates toll-like receptor 3-induced preeclampsia-like symptoms in mice. Hypertension. (2011) 58:489-96. doi: 10.1161/HYPERTENSIONAHA.111.172114

124. Chatterjee P, Weaver LE, Doersch KM, Kopriva SE, Chiasson VL, Allen SJ, et al. Placental Toll-like receptor 3 and Toll-like receptor $7 / 8$ activation contributes to preeclampsia in humans and mice. PLoS ONE. (2012) 7:e41884. doi: 10.1371/journal.pone.0041884

125. Pineda A, Verdin-Terán SL, Camacho A, Moreno-Fierros L. Expression of toll-like receptor TLR-2, TLR-3, TLR-4 and TLR-9 is increased in placentas from patients with preeclampsia. Arch Med Res. (2011) 42:382-91. doi: 10.1016/j.arcmed.2011.08.003

126. Panda B, Panda A, Ueda I, Abrahams VM, Norwitz ER, Stanic AK, et al. Dendritic cells in the circulation of women with preeclampsia demonstrate a pro-inflammatory bias secondary to dysregulation of TLR receptors. J Reprod Immunol. (2012) 94:210-5. doi: 10.1016/j.jri.2012.01.008
127. He B, Yang X, Li Y, Huang D, Xu X, Yang W, et al. TLR9 (Toll-Like Receptor 9) agonist suppresses angiogenesis by differentially regulating VEGFA (Vascular Endothelial Growth Factor A) and sFLT1 (Soluble Vascular Endothelial Growth Factor Receptor 1) in preeclampsia. Hypertension. (2018) 71:671-80. doi: 10.1161/HYPERTENSIONAHA.117.10510

128. Wang J, Wu F, Xie Q, Liu X, Tian F, Xu W, et al. Anakinra and etanercept prevent embryo loss in pregnant nonobese diabetic mice. Reproduction. (2015) 149:84. doi: 10.1530/REP-14-0614

129. Bhat NM, Mithal A, Bieber MM, Herzenberg LA, Teng NN. Human CD5+ B lymphocytes (B-1 cells) decrease in peripheral blood during pregnancy. J Reprod Immunol. (1995) 28:53-60. doi: 10.1016/0165-0378 (94)00907-o

130. Eledel RH, Bassuoni MA, Radwan WM, Masoud A, Eldeeb SM. CD19+ CD5+ B-cell expansion and risk of pre-eclampsia. Menoufia Med J. (2016) 29:319. doi: 10.4103/1110-2098.192433

131. Saito S, Nakashima A, Shima T, Ito M. Th1/Th2/Th17 and regulatory Tcell paradigm in pregnancy. Am J Reprod Immunol. (2010) 63:601-10. doi: 10.1111/j.1600-0897.2010.00852.x

132. Zhong X, Gao W, Degauque N, Bai C, Lu Y, Kenny J, et al. Reciprocal generation of Th1/Th17 and Treg cells by B1 and B2 B cells. Eur J Immunol. (2007) 37:2400-4. doi: 10.1002/eji.200737296

133. Lamarca B, Parrish MR, Wallace K. Agonistic autoantibodies to the angiotensin II type i receptor cause pathophysiologic characteristics of preeclampsia. Gender Med. (2012) 9:139-46. doi: 10.1016/j.genm.2012.03.001

134. Robinson CJ, Johnson DD, Chang EY, Armstrong DM, Wang W. Evaluation of placenta growth factor and soluble Fms-like tyrosine kinase 1 receptor levels in mild and severe preeclampsia. Am J Obstet Gynecol. (2006) 195:2559. doi: 10.1016/j.ajog.2005.12.049

135. Erez O, Romero R, Espinoza J, Fu W, Todem D, Kusanovic JP, et al. The change in concentrations of angiogenic and anti-angiogenic factors in maternal plasma between the first and second trimesters in risk assessment for the subsequent development of preeclampsia and smallfor-gestational age. J Matern Fetal Neonatal Med. (2008) 21:279-87. doi: 10.1080/14767050802034545

136. Wang W, Irani RA, Zhang Y, Ramin SM, Blackwell SC, Tao L, et al. Autoantibody-mediated complement C3a receptor activation contributes to the pathogenesis of preeclampsia. Hypertension. (2012) 60:712-21. doi: 10.1161/HYPERTENSIONAHA.112.191817

137. Siddiqui AH, Irani RA, Blackwell SC, Ramin SM, Kellems RE, Xia Y. Angiotensin receptor agonistic autoantibody is highly prevalent in preeclampsia: correlation with disease severity. Hypertension. (2010) 55:38693. doi: 10.1161/HYPERTENSIONAHA.109.140061

138. LaMarca B, Wallace K, Herse F, Wallukat G, Martin JNJr, Weimer $A$, et al. Hypertension in response to placental ischemia during pregnancy: role of B lymphocytes. Hypertension. (2011) 57:865-71. doi: 10.1161/HYPERTENSIONAHA.110.167569

139. Binder CJ. Natural IgM antibodies against oxidation-specific epitopes. J Clin Immunol. (2010) 30:56-60. doi: 10.1007/s10875-010-9396-3

140. Laule CF, Odean EJ, Wing CR, Root KM, Towner KJ, Hamm CM, et al. Role of B1 and B2 lymphocytes in placental ischemia-induced hypertension. Am J Physiol Heart Circ Physiol. (2019) 317:H732-H742. doi: 10.1152/ajpheart.00132.2019

141. Fox A, Maddox JF, de Veer MJ, Meeusen EN. $\gamma \delta T C R+$ cells of the pregnant ovine uterus express variable $\mathrm{T}$ cell receptors and contain granulysin. $J$ Reprod Immunol. (2010) 84:52-6. doi: 10.1016/j.jri.2009.10.003

142. Fan D-X, Duan J, Li M-Q, Xu B, Li D-J, Jin L-P. The decidual gammadelta $\mathrm{T}$ cells up-regulate the biological functions of trophoblasts via IL10 secretion in early human pregnancy. Clin Immunol. (2011) 141:284-92. doi: 10.1016/j.clim.2011.07.008

143. Talukdar A, Rai R, Sharma KA, Rao D, Sharma A. Peripheral Gamma Delta $\mathrm{T}$ cells secrete inflammatory cytokines in women with idiopathic recurrent pregnancy loss. Cytokine. (2018) 102:117-22. doi: 10.1016/j.cyto.2017.07.018

144. Chatterjee P, Chiasson VL, Seerangan G, De Guzman E, Milad M, Bounds $\mathrm{KR}$, et al. Depletion of MHC class II invariant chain peptide or $\gamma-\delta \mathrm{T}$ cells ameliorates experimental preeclampsia. Clin Sci. (2017) 131:2047-58 doi: 10.1042/CS20171008 
145. Wu W, Yang H, Feng Y, Zhang P, Li S, Wang X, et al. Polymorphisms in complement genes and risk of preeclampsia in Taiyuan, China. Inflamm Res. (2016) 65:837-45. doi: 10.1007/s00011-016-0968-4

146. Lim R, Lappas M. Decreased expression of complement 3a receptor (C3aR) in human placentas from severe preeclamptic pregnancies. Eur J Obstetr Gynecol Reprod Biol. (2012) 165:194-8. doi: 10.1016/j.ejogrb.2012. 08.003

147. Lokki AI, Heikkinen-Eloranta J, Jarva H, Saisto T, Lokki M-L, Laivuori H, et al. Complement activation and regulation in preeclamptic placenta. Front Immunol. (2014) 5:312. doi: 10.3389/fimmu.2014.00312

148. Burwick RM, Velásquez JA, Valencia CM, Gutiérrez-Marín J, Edna-Estrada F, Silva JL, et al. Terminal complement activation in preeclampsia. Obstet Gynecol. (2018) 132:1477-85. doi: 10.1097/AOG.0000000000002980

149. Banadakoppa M, Vidaeff AC, Yallampalli U, Ramin SM, Belfort MA, Yallampalli C. Complement split products in amniotic fluid in pregnancies subsequently developing early-onset preeclampsia. Dis Markers. (2015) 2015. doi: $10.1155 / 2015 / 263109$

150. Jia K, Ma L, Wu S, Yan W. Serum levels of complement factors $\mathrm{Clq}, \mathrm{Bb}$, and $\mathrm{H}$ in normal pregnancy and severe pre-eclampsia. Med Sci Monit. (2019) 25:7087. doi: 10.12659/MSM.915777

151. He Y, Xu B, Song D, Yu F, Chen Q, Zhao M. Expression of the complement system's activation factors in plasma of patients with early/lateonset severe pre-eclampsia. Am J Reprod Immunol. (2016) 76:205-11. doi: $10.1111 /$ aji. 12541

152. Guller S, Tang Z, Ma YY, Di Santo S, Sager R, Schneider H. Protein composition of microparticles shed from human placenta during placental perfusion: Potential role in angiogenesis and fibrinolysis in preeclampsia. Placenta. (2011) 32:63-9. doi: 10.1016/j.placenta.2010.10.011

153. Chen Y, Huang Y, Jiang R, Teng Y. Syncytiotrophoblast-derived microparticle shedding in early-onset and late-onset severe pre-eclampsia. Int J Gynaecol Obstet. (2012) 119:234-8. doi: 10.1016/j.ijgo.2012.07.010

154. Goswami D, Tannetta DS, Magee LA, Fuchisawa A, Redman CW, Sargent IL, et al. Excess syncytiotrophoblast microparticle shedding is a feature of earlyonset pre-eclampsia, but not normotensive intrauterine growth restriction. Placenta. (2006) 27:56-61. doi: 10.1016/j.placenta.2004.11.007

155. Gilani SI, Weissgerber TL, Garovic VD, Jayachandran M. Preeclampsia and extracellular vesicles. Curr Hypertens Rep. (2016) 18:68. doi: 10.1007/s11906-016-0678-x

156. Dragovic RA, Southcombe JH, Tannetta DS, Redman CW, Sargent IL. Multicolor flow cytometry and nanoparticle tracking analysis of extracellular vesicles in the plasma of normal pregnant and pre-eclamptic women. Biol Reprod. (2013) 89:151. doi: 10.1095/biolreprod.113.113266

157. Gardiner C, Tannetta DS, Simms CA, Harrison P, Redman CW, Sargent IL. Syncytiotrophoblast microvesicles released from pre-eclampsia placentae exhibit increased tissue factor activity. PLoS ONE. (2011) 6:e26313. doi: 10.1371/journal.pone.0026313

158. Redman CW, Staff AC. Preeclampsia, biomarkers, syncytiotrophoblast stress, and placental capacity. Am J Obstet Gynecol. (2015) 213(4 Suppl.):S9 e1-11. doi: 10.1016/j.ajog.2015.08.003

159. Yonekura Collier AR, Zsengeller Z, Pernicone E, Salahuddin S, Khankin EV, Karumanchi SA. Placental sFLT1 is associated with complement activation and syncytiotrophoblast damage in preeclampsia. Hypertens Pregnancy. (2019) 38:193-9. doi: 10.1080/10641955.2019.1640725

160. Flint EJ, Cerdeira AS, Redman CW, Vatish M. The role of angiogenic factors in the management of preeclampsia. Acta Obstet Gynecol Scand. (2019) 98:700-7. doi: 10.1111/aogs.13540

161. O'Brien M, Baczyk D, Kingdom JC. Endothelial dysfunction in severe preeclampsia is mediated by soluble factors, rather than extracellular vesicles. Sci Rep. (2017) 7:5887. doi: 10.1038/s41598-017-06178-z

162. Chatterjee P, Chiasson VL, Pinzur L, Raveh S, Abraham E, Jones KA, et al. Human placenta-derived stromal cells decrease inflammation, placental injury and blood pressure in hypertensive pregnant mice. Clin Sci. (2016) 130:513-23. doi: 10.1042/CS20150555

163. Wang M, Yuan Q, Xie L. Mesenchymal stem cell-based immunomodulation: properties and clinical application. Stem Cells Int. (2018) 2018:3057624. doi: 10.1155/2018/3057624

164. Huang P, Lin LM, Wu XY, Tang QL, Feng XY, Lin GY, et al. Differentiation of human umbilical cord Wharton's jelly-derived mesenchymal stem cells into germ-like cells in vitro. J Cell Biochem. (2010) 109:747-54. doi: $10.1002 / j \mathrm{cb} .22453$

165. Pelekanos RA, Sardesai VS, Futrega K, Lott WB, Kuhn M, Doran MR. Isolation and expansion of mesenchymal stem/stromal cells derived from human placenta tissue. JoVE. (2016) 112:e54204. doi: 10.3791/54204

166. Ayenehdeh JM, Niknam B, Rasouli S, Hashemi SM, Rahavi H, Rezaei N, et al. Immunomodulatory and protective effects of adipose tissue-derived mesenchymal stem cells in an allograft islet composite transplantation for experimental autoimmune type 1 diabetes. Immunol Lett. (2017) 188:21-31. doi: 10.1016/j.imlet.2017.05.006

167. Suvakov S, Cubro H, White WM, Butler Tobah YS, Weissgerber TL, Jordan $\mathrm{KL}$, et al. Targeting senescence improves angiogenic potential of adiposederived mesenchymal stem cells in patients with preeclampsia. Biol Sex Differ. (2019) 10:49. doi: 10.1186/s13293-019-0

168. Dimitrov R, Kyurkchiev D, Timeva T, Yunakova M, Stamenova M, Shterev A, et al. First-trimester human decidua contains a population of mesenchymal stem cells. Fertil Steril. (2010) 93:210-9. doi: 10.1016/j.fertnstert.2008.09.061

169. Nakashima A, Shima T, Inada K, Ito M, Saito S. The balance of the immune system between $\mathrm{T}$ cells and NK cells in miscarriage. Am J Reprod Immunol. (2012) 67:304-10. doi: 10.1111/j.1600-0897.2012.01115.x

170. Croxatto D, Vacca P, Canegallo F, Conte R, Venturini PL, Moretta L, et al. Stromal cells from human decidua exert a strong inhibitory effect on NK cell function and dendritic cell differentiation. PLoS ONE. (2014) 9:e89006. doi: 10.1371/journal.pone.0089006

171. Fu Q, Man X, Yu M, Chu Y, Luan X, Piao H, et al. Human decidua mesenchymal stem cells regulate decidual natural killer cell function via interactions between collagen and leukocyte associated immunoglobulin like receptor 1. Mol Med Rep. (2017) 16:2791-8. doi: 10.3892/mmr.2017.6921

172. Sotiropoulou PA, Perez SA, Gritzapis AD, Baxevanis CN, Papamichail M. Interactions between human mesenchymal stem cells and natural killer cells. Stem Cells. (2006) 24:74-85. doi: 10.1634/stemcells.2004-0359

173. Michelo CM, Fasse E, van Cranenbroek B, Linda K, van der Meer A, Abdelrazik $\mathrm{H}$, et al. Added effects of dexamethasone and mesenchymal stem cells on early Natural Killer cell activation. Transpl Immunol. (2016) 37:1-9. doi: 10.1016/j.trim.2016.04.008

174. Harris SG, Padilla J, Koumas L, Ray D, Phipps RP. Prostaglandins as modulators of immunity. Trends Immunol. (2002) 23:144-50. doi: 10.1016/s1471-4906(01)02154-8

175. Aggarwal S, Pittenger MF. Human mesenchymal stem cells modulate allogeneic immune cell responses. Blood. (2005) 105:1815-22. doi: 10.1182/blood-2004-04-1559

176. Pedersen EB, Christensen NJ, Christensen P, Johannesen P, Kornerup HJ, Kristensen S, et al. Preeclampsia - a state of prostaglandin deficiency? Urinary prostaglandin excretion, the renin-aldosterone system, and circulating catecholamines in preeclampsia. Hypertension. (1983) 5:105-11. doi: 10.1161/01.hyp.5.1.105

177. Abumaree $\mathrm{MH}, \mathrm{Al}$ Jumah $\mathrm{MA}$, Kalionis B, Jawdat $\mathrm{D}, \mathrm{Al}$ Khaldi A, Abomaray FM, et al. Human placental mesenchymal stem cells (pMSCs) play a role as immune suppressive cells by shifting macrophage differentiation from inflammatory M1 to anti-inflammatory M2 macrophages. Stem Cell Rev Rep. (2013) 9:620-41. doi: 10.1007/s12015-013-9455-2

178. Jin L, Deng Z, Zhang J, Yang C, Liu J, Han W, et al. Mesenchymal stem cells promote type 2 macrophage polarization to ameliorate the myocardial injury caused by diabetic cardiomyopathy. J Transl Med. (2019) 17:251. doi: 10.1186/s12967-019-1999-8

179. Németh K, Leelahavanichkul A, Yuen PS, Mayer B, Parmelee A, Doi $\mathrm{K}$, et al. Bone marrow stromal cells attenuate sepsis via prostaglandin E 2-dependent reprogramming of host macrophages to increase their interleukin-10 production. Nat Med. (2009) 15:42. doi: 10.1038/ nm.1905

180. Stock SJ, Norman JE. Medicines in pregnancy. F1000Res. (2019) 8:911. doi: 10.12688/f1000research.17535.1

181. Kennedy DA, Lupattelli A, Koren G, Nordeng H. Safety classification of herbal medicines used in pregnancy in a multinational study. $B M C$ Complement Altern Med. (2016) 16:102. doi: 10.1186/s12906-016-1079-z

182. Vishnyakova P, Elchaninov A, Fatkhudinov T, Sukhikh G. Role of the monocyte-macrophage system in normal pregnancy and preeclampsia. Int J Mol Sci. (2019) 20:3695. doi: 10.3390/ijms20153695 
183. Gill M, Motta-Mejia C, Kandzija N, Cooke W, Zhang W, Cerdeira AS, et al. Placental syncytiotrophoblast-derived extracellular vesicles carry active NEP (Neprilysin) and are increased in preeclampsia. Hypertension. (2019) 73:1112-9. doi: 10.1161/HYPERTENSIONAHA.119.12707

184. Bavishi C, Messerli FH, Kadosh B, Ruilope LM, Kario K. Role of neprilysin inhibitor combinations in hypertension: insights from hypertension and heart failure trials. Eur Heart J. (2015) 36:1967-73. doi: 10.1093/eurheartj/ehv142

185. Dunlop AL, Mulle JG, Ferranti EP, Edwards S, Dunn AB, Corwin EJ. Maternal microbiome and pregnancy outcomes that impact infant health: a review. Adv Neonatal Care. (2015) 15:377-85. doi: 10.1097/ANC.0000000000000218

186. Brantsaeter AL, Myhre R, Haugen M, Myking S, Sengpiel V, Magnus P, et al. Intake of probiotic food and risk of preeclampsia in primiparous women: the Norwegian Mother and Child Cohort Study. Am J Epidemiol. (2011) 174:807-15. doi: 10.1093/aje/kwr168

187. Pelzer E, Gomez-Arango LF, Barrett HL, Nitert MD. Review: maternal health and the placental microbiome. Placenta. (2017) 54:30-7. doi: 10.1016/j.placenta.2016.12.003

188. Beckers KF, Sones JL. Maternal microbiome and the hypertensive disorder of pregnancy, preeclampsia. Am J Physiol Heart Circ Physiol. (2020) 318:H1-10. doi: 10.1152/ajpheart.00469.2019

189. Ouyang W, O'Garra A. IL-10 family cytokines IL-10 and IL-22: from basic science to clinical translation. Immunity. (2019) 50:871-91. doi: 10.1016/j.immuni.2019.03.020

190. Lai Z, Kalkunte S, Sharma S. A critical role of interleukin-10 in modulating hypoxia-induced preeclampsia-like disease in mice. Hypertension. (2011) 57:505-14. doi: 10.1161/HYPERTENSIONAHA.110.163329

191. Tinsley JH, South S, Chiasson VL, Mitchell BM. Interleukin-10 reduces inflammation, endothelial dysfunction, and blood pressure in hypertensive pregnant rats. Am J Physiol Regul Integr Comp Physiol. (2010) 298:R713-9. doi: 10.1152/ajpregu.00712.2009

192. Ostensen M, Lockshin M, Doria A, Valesini G, Meroni P, Gordon C, et al. Update on safety during pregnancy of biological agents and some immunosuppressive anti-rheumatic drugs. Rheumatology. (2008) 47(Suppl. 3):iii28-31. doi: 10.1093/rheumatology/ken168

193. Roth A, Rottinghaus ST, Hill A, Bachman ES, Kim JS, Schrezenmeier H, et al. Ravulizumab (ALXN1210) in patients with paroxysmal nocturnal hemoglobinuria: results of 2 phase 1b/2 studies. Blood Adv. (2018) 2:2176-85. doi: 10.1182/bloodadvances.2018020644

194. Patra MC, Choi S. Recent progress in the development of Toll-like receptor (TLR) antagonists. Expert Opin Ther Pat. (2016) 26:719-30. doi: 10.1080/13543776.2016.1185415

195. Smith JP, Bingaman SI, Ruggiero F, Mauger DT, Mukherjee A, McGovern $\mathrm{CO}$, et al. Therapy with the opioid antagonist naltrexone promotes mucosal healing in active Crohn's disease: a randomized placebo-controlled trial. Dig Dis Sci. (2011) 56:2088-97. doi: 10.1007/s10620-011-1653-7

196. Cant R, Dalgleish AG, Allen RL. Naltrexone inhibits IL-6 and TNFalpha production in human immune cell subsets following stimulation with ligands for intracellular toll-like receptors. Front Immunol. (2017) 8:809. doi: 10.3389/fimmu.2017.00809

197. Sun J, Wang S, Wei YH. Reproductive toxicity of Rhizoma Sparganii (Sparganium stoloniferum Buch.-Ham.) in mice: mechanisms of antiangiogenesis and anti-estrogen pharmacologic activities. J Ethnopharmacol. (2011) 137:1498-503. doi: 10.1016/j.jep.2011.08.026

198. Caputi V, Giron MC. Microbiome-gut-brain axis and toll-like receptors in Parkinson's Disease. Int J Mol Sci. (2018) 19:1689. doi: 10.3390/ijms190 61689

199. Abais-Battad JM, Dasinger JH, Fehrenbach DJ, Mattson DL. Novel adaptive and innate immunity targets in hypertension. Pharmacol Res. (2017) 120:109-15. doi: 10.1016/j.phrs.2017.03.015

200. Liu M, Peng J, Tai N, Pearson JA, Hu C, Guo J, et al. Toll-like receptor 9 negatively regulates pancreatic islet beta cell growth and function in a mouse model of type 1 diabetes. Diabetologia. (2018) 61:2333-43. doi: 10.1007/s00125-018-4705-0
201. Thaxton JE, Romero R, Sharma S. TLR9 activation coupled to IL10 deficiency induces adverse pregnancy outcomes. J Immunol. (2009) 183:1144-54. doi: 10.4049/jimmunol.0900788

202. Kuzmich NN, Sivak KV, Chubarev VN, Porozov YB, SavateevaLyubimova TN, Peri F. TLR4 signaling pathway modulators as potential therapeutics in inflammation and sepsis. Vaccines. (2017) 5:34. doi: $10.3390 /$ vaccines5040034

203. Lan J, Zhao Y, Dong F, Yan Z, Zheng W, Fan J, et al. Meta-analysis of the effect and safety of berberine in the treatment of type 2 diabetes mellitus, hyperlipemia and hypertension. J Ethnopharmacol. (2015) 161:6981. doi: 10.1016/j.jep.2014.09.049

204. Xie L, Zhang D, Ma H, He H, Xia Q, Shen W, et al. The effect of berberine on reproduction and metabolism in women with polycystic ovary syndrome: a systematic review and meta-analysis of randomized control trials. Evid Based Complement Alternat Med. (2019) 2019:7918631. doi: 10.1155/2019/7918631

205. Chu M, Ding R, Chu ZY, Zhang MB, Liu XY, Xie SH, et al. Role of berberine in anti-bacterial as a high-affinity LPS antagonist binding to TLR4/MD-2 receptor. BMC Complement Altern Med. (2014) 14:89. doi: 10.1186/1472-6882-14-89

206. National Center for Complementary and Integrative Health. Goldenseal. (2016) Available online at: https://www.nccih.nih.gov/health/goldenseal (accessed May 16, 2020)

207. Pareek A, Suthar M, Rathore GS, Bansal V. Feverfew (Tanacetum parthenium L.): a systematic review. Pharmacogn Rev. (2011) 5:103-10. doi: 10.4103/0973-7847.79105

208. Ernst E. Herbal medicinal products during pregnancy: are they safe? BJOG. (2002) 109:227-35. doi: 10.1111/j.1471-0528.2002.t01-1-01009.x

209. Zuurbier CJ, Abbate A, Cabrera-Fuentes HA, Cohen MV, Collino M, De Kleijn DPV, et al. Innate immunity as a target for acute cardioprotection. Cardiovasc Res. (2019) 115:1131-42. doi: 10.1093/cvr/cvy304

210. Morrison TJ, Jackson MV, Cunningham EK, Kissenpfennig A, McAuley DF, O'Kane CM, et al. Mesenchymal stromal cells modulate macrophages in clinically relevant lung injury models by extracellular vesicle mitochondrial transfer. Am J Respir Crit Care Med. (2017) 196:1275-86. doi: 10.1164/rccm.201701-0170OC

211. Tronnes JN, Lupattelli A, Nordeng H. Safety profile of medication used during pregnancy: results of a multinational European study. Pharmacoepidemiol Drug Saf. (2017) 26:802-11. doi: 10.1002/pds.4213

212. Sheffield JS, Siegel D, Mirochnick M, Heine RP, Nguyen C, Bergman KL, et al. Designing drug trials: considerations for pregnant women. Clin Infect Dis. (2014) 59(Suppl. 7):S437-44. doi: 10.1093/cid/ciu709

213. Young AN, Moyle-Heyrman G, Kim JJ, Burdette JE. Microphysiologic systems in female reproductive biology. Exp Biol Med. (2017) 242:1690-700. doi: $10.1177 / 1535370217697386$

214. Gao W, Xiong $\mathrm{Y}$, Li Q, Yang H. Inhibition of toll-like receptor signaling as a promising therapy for inflammatory diseases: a journey from molecular to nano therapeutics. Front Physiol. (2017) 8:508. doi: 10.3389/fphys.2017.00508

215. Myatt L, Roberts JM. Preeclampsia: syndrome or disease? Curr Hypertens Rep. (2015) 17:83. doi: 10.1007/s11906-015-0595-4

216. Miller CP, Shin W, Ahn EH, Kim HJ, Kim D-H. Engineering microphysiological immune system responses on chips. Trends Biotechnol. (2020) 38:857-72. doi: 10.1016/j.tibtech.2020.01.003

Conflict of Interest: The authors declare that the research was conducted in the absence of any commercial or financial relationships that could be construed as a potential conflict of interest.

Copyright (c) 2020 Aneman, Pienaar, Suvakov, Simic, Garovic and McClements. This is an open-access article distributed under the terms of the Creative Commons Attribution License (CC BY). The use, distribution or reproduction in other forums is permitted, provided the original author(s) and the copyright owner(s) are credited and that the original publication in this journal is cited, in accordance with accepted academic practice. No use, distribution or reproduction is permitted which does not comply with these terms. 